NBER WORKING PAPER SERIES

\title{
THE LABOR DEMAND CURVE IS DOWNWARD SLOPING: REEXAMINING THE IMPACT OF IMMIGRATION ON THE LABOR MARKET
}

\author{
George J. Borjas \\ Working Paper 9755 \\ http://www.nber.org/papers/w9755

\section{NATIONAL BUREAU OF ECONOMIC RESEARCH 1050 Massachusetts Avenue Cambridge, MA 02138} \\ June 2003
}

The views expressed herein are those of the authors and not necessarily those of the National Bureau of Economic Research.

C 2003 by George J. Borjas. All rights reserved. Short sections of text not to exceed two paragraphs, may be quoted without explicit permission provided that full credit including (C) notice, is given to the source. 
The Labor Demand Curve is Downward Sloping: Reexamining the Impact of Immigration on the Labor Market

George J. Borjas

NBER Working Paper No. 9755

June 2003

JEL No. J1, J6

\begin{abstract}
Immigration is not evenly balanced across groups of workers that have the same education but differ in their work experience, and the nature of the supply imbalance changes over time. This paper develops a new approach for estimating the labor market impact of immigration by exploiting this variation in supply shifts across education-experience groups. I assume that similarly educated workers with different levels of experience participate in a national labor market and are not perfect substitutes. The analysis indicates that immigration lowers the wage of competing workers: a 10 percent increase in supply reduces wages by 3 to 4 percent.
\end{abstract}

George J. Borjas

Kennedy School of Government

Harvard University

79 JFK Street

Cambridge, MA 02138

and NBER

gborjas@harvard.edu 


\section{THE LABOR DEMAND CURVE IS DOWNWARD SLOPING: REEXAMINING THE IMPACT OF IMMIGRATION ON THE LABOR MARKET*

\author{
George J. Borjas
}

"After World War I, laws were passed severely limiting immigration. Only a trickle of immigrants has been admitted since then. . .By keeping labor supply down, immigration policy tends to keep wages high"

Paul Samuelson, Economics [1964]

\section{Introduction}

Do immigrants harm or improve the employment opportunities of native workers? As

Paul Samuelson's assertion suggests, the textbook model of a competitive labor market predicts that an immigrant influx should lower the wage of competing factors. ${ }^{1}$

Despite the intuitive appeal of this theoretical implication and despite the large number of careful studies in the literature, the existing evidence provides a mixed and confusing set of results. The measured impact of immigration on the wage of native workers fluctuates widely from study to study (and sometimes even within the same study), but seems to cluster around zero. A widely cited survey by Friedberg and Hunt [1995, p. 42] concludes that "the effect of immigration on the labor market outcomes of natives is small." Similarly, the 1997 National Academy of Sciences report on the economic impact of immigration argues that "the weight of the empirical evidence suggests that the impact of immigration on the wages of competing native workers is small" [Smith and Edmonston 1997, p. 220]. These conclusions are potentially inconsistent with the textbook model because the immigrant supply shock in recent decades has

\footnotetext{
* I am grateful to Daron Acemoglu, Joshua Angrist, David Autor, Richard Freeman, Daniel Hamermesh, Lawrence Katz, Michael Kremer, Casey Mulligan, Stephen Trejo, and a referee for helpful comments and suggestions, and to the Smith-Richardson Foundation for financial support.

1 The historical context of Samuelson's [1964, p. 552] assertion is interesting. He was writing just before the enactment of the 1965 Amendments to the Immigration and Nationality Act, the major policy shift that initiated the resurgence of large-scale immigration.
} 
been very large, and most studies of labor demand (outside the immigration context) conclude that the labor demand curve is not perfectly elastic [Hamermesh 1993].

This paper presents a new approach for thinking about and estimating the labor market impact of immigration. Most existing studies exploit the geographic clustering of immigrants and use differences across local labor markets to identify the impact of immigration. This framework has been troublesome because it ignores the strong currents that tend to equalize economic conditions across cities and regions. In this paper, I argue that by paying closer attention to the characteristics that define a skill group — and, in particular, by using the insight that both schooling and work experience play a role in defining a skill group—one can make substantial progress in determining whether immigration influences the employment opportunities of native workers.

My analysis uses data drawn from the 1960-1990 U.S. Decennial Censuses, as well as the 1998-2001 Current Population Surveys, and assumes that workers with the same education but different levels of work experience participate in a national labor market and are not perfect substitutes. It turns out that immigration — even within a particular schooling group —is not balanced evenly across all experience cells in that group, and the nature of the supply imbalance changes over time. This fact generates a great deal of variation - across schooling groups, experience cells, and over time - that helps to identify the impact of immigration on the labor market. Most importantly, the size of the native workforce in each of the skill groups is relatively fixed, so that there is less potential for native flows to contaminate the comparison of outcomes across skill groups. In contrast to the confusing array of results that now permeate the literature, the evidence consistently suggests that immigration has indeed harmed the employment opportunities of competing native workers. 


\section{Measuring the Labor Market Impact of Immigration}

The laws of supply and demand have unambiguous implications for how immigration should affect labor market conditions in the short run. The shift in supply lowers the real wage of competing native workers. Further, as long as the native supply curve is upward sloping, immigration should also reduce the amount of labor supplied by the native workforce.

If one could observe a number of closed labor markets that immigrants penetrate randomly, one could then relate the change in the wage of workers in a particular skill group to the immigrant share in the relevant population. A negative correlation (i.e., native wages are lower in those markets penetrated by immigrants) would indicate that immigrants worsen the employment opportunities of competing native workers.

In the United States, immigrants cluster in a small number of geographic areas. In 1990, for example, 32.5 percent of the immigrant population lived in only three metropolitan areas (Los Angeles, New York, and Miami). In contrast, only 11.6 percent of the native population clustered in the three largest metropolitan areas housing natives (New York, Los Angeles, and Chicago). Practically all empirical studies in the literature, beginning with Grossman [1982], exploit this demographic feature to identify the labor market impact of immigration. The typical study defines a metropolitan area as the labor market that is being penetrated by immigrants. The study then goes on to calculate a "spatial correlation" measuring the relation between the native wage in a locality and the relative number of immigrants in that locality. These correlations are usually negative, but very weak. ${ }^{2}$ The best known spatial correlations are reported in Card's

\footnotetext{
2 Representative studies include Altonji and Card [1991], Borjas [1987], LaLonde and Topel [1991], Pischke and Velling [1997], and Schoeni [1997]. Friedberg [2001] presents a rare study that uses the supply shock in an occupation to identify the labor market impact of immigration in the Israeli labor market. Although the raw Israeli data suggest a substantial negative impact, correcting for the endogeneity of occupational choice leads to the usual result that immigration has little impact on the wage structure. Card [2001] uses data on occupation and metropolitan area to define skill groups and finds that immigration has a slight negative effect.
} 
[1990] influential study of the Mariel flow. Card compared labor market conditions in Miami and in other cities before and after the Marielitos increased Miami's workforce by 7 percent. Card's difference-in-differences estimate of the spatial correlation indicated that this sudden and unexpected immigrant influx did not have a discernable effect on employment and wages in Miami's labor market. ${ }^{3}$

Recent studies have raised two questions about the validity of interpreting weak spatial correlations as evidence that immigration has no labor market impact. First, immigrants may not be randomly distributed across labor markets. If immigrants endogenously cluster in cities with thriving economies, there would be a spurious positive correlation between immigration and wages. ${ }^{4}$ Second, natives may respond to the wage impact of immigration on a local labor market by moving their labor or capital to other cities. These factor flows would re-equilibrate the market. As a result, a comparison of the economic opportunities facing native workers in different cities would show little or no difference because, in the end, immigration affected every city, not just the ones that actually received immigrants. ${ }^{5}$

Because the local labor market may adjust to immigration, Borjas, Freeman, and Katz [1997] suggested changing the unit of analysis to the national level. If the aggregate technology can be described by a CES production function with two skill groups, the relative wage of the two

\footnotetext{
${ }^{3}$ Angrist and Krueger [1999] replicate Card's study using an alternative time period, and find that a "phantom" influx of immigrants (in the sense that had it not been for a policy intervention, many immigrants would likely have arrived) had a sizable adverse effect on Miami's labor market. This result suggests that many other factors influence labor market conditions in Miami and comparison cities. At the least, one should be cautious when interpreting the spatial correlations estimated from comparisons of specific localities.

${ }^{4}$ Borjas [2001] presents evidence indicating that new immigrants belonging to a particular schooling group tend to settle in those regions that offer the highest return for their skills.

${ }^{5}$ Borjas, Freeman, and Katz [1997] and Card [2001] provide the first attempts to jointly analyze labor market outcomes and native migration decisions. The two studies reach different conclusions. Card reports a slight positive correlation between the 1985-90 rate of growth in the native population and the immigrant supply shock by
} 
groups depends linearly on their relative quantities. By restricting the analysis to two skill groups, the "factor proportions approach" precludes the estimation of the impact of immigration—-there is only one observation at any point in time (usually a Census year), giving relative wages and relative employment. As a result, the typical application of this approach compares the actual supplies of workers in particular skill groups to those that would have been observed in the absence of immigration, and then uses outside information on labor demand elasticities to simulate the consequences of immigration. The immigrant flow to the United States in the 1980s and 1990s was relatively low-skill. Not surprisingly, the Borjas-Freeman-Katz [1997] simulation finds that immigration worsened the relative economic status of low-skill workers.

Despite all of the confusion in the literature, the available evidence teaches two important lessons. First, the study of the geographic dispersion in native employment opportunities is not an effective way for measuring the economic impact of immigration; the local labor market can adjust in far too many ways to provide a reasonable analogue to the "closed market" economy that underlies the textbook supply-and-demand framework. Second, the factor proportions approach is ultimately unsatisfactory. It departs from the valuable tradition of empirical research in labor economics that attempts to estimate the impact of labor market shocks by directly observing how those shocks affect some workers and not others. For a given elasticity of substitution, the approach mechanically predicts the relative wage consequences of supply shifts.

Ideally, one would want to estimate directly how immigration alters the employment opportunities of a particular skill group. As noted above, by aggregating workers into groups based on educational attainment, there is just too little variation to examine how supply shocks affect relative wages. However, the human capital literature emphasizes that schooling is not the

metropolitan area, while Borjas, Freeman, and Katz report a negative correlation between native net migration in 1970-90 and immigration by state — once one standardizes for the pre-existing migration trends. 
only — and perhaps not even the most important_-determinant of a worker's skills. The seminal work of Becker [1975] and Mincer [1974] stressed that skills are acquired both before and after a person enters the labor market. I will assume that workers who have the same schooling, but who have different levels of experience, are imperfect substitutes in production. As a result, a skill group should be defined in terms of both schooling and labor market experience.

To see how this insight can provide a fruitful approach to the empirical analysis of the labor market impact of immigration, consider the following example. Recent immigration has increased the relative supply of high school dropouts substantially. The labor market implications of this supply shock clearly depend on how the distribution of work experience in the immigrant population contrasts with that of natives. After all, one particular set of native high school dropouts would likely be affected if all of the new low-skill immigrants were very young, and a very different set would be affected if the immigrants were near retirement age.

It is unlikely that similarly educated workers with very different levels of work experience are perfect substitutes [Welch 1979; Card and Lemieux 2001]. The definition of a skill group in terms of both education and experience provides a great deal more independent variation in the immigrant supply shock that can be used to identify how immigration alters the economic opportunities facing particular groups of native workers.

\section{Data}

The empirical analysis uses data drawn from the 1960, 1970, 1980, and 1990 Public Use Microdata Samples (PUMS) of the Decennial Census, and the 1999, 2000, and 2001 Annual Demographic Supplement of the Current Population Surveys (CPS). I pool all three of the CPS surveys and refer to these pooled data as the "2000" cross-section. The analysis is restricted to 
men aged 18-64 who participate in the civilian labor force. A person is defined to be an immigrant if he was born abroad and is either a non-citizen or a naturalized citizen; all other persons are classified as natives. Appendix 1 provides a detailed description of the construction of the data extracts and of the variables used in the analysis.

As noted above, I use both educational attainment and work experience to sort workers into particular skill groups. In particular, I classify the men into four distinct education groups: persons who are high school dropouts (i.e., they have less than twelve years of completed schooling), high school graduates (they have exactly twelve years of schooling), persons who have some college (they have between thirteen and fifteen years of schooling), and college graduates (they have at least sixteen years of schooling).

The classification of workers into experience groups is bound to be imprecise because the Census does not provide any measure of labor market experience or of the age at which a worker first enters the labor market. I initially define work experience as the number of years that have elapsed since the person completed school. This approximation is reasonably accurate for most native men, but would surely contain serious measurement errors if the calculations were also conducted for women, particularly in the earlier cross-sections when the female labor force participation rate was much lower.

Equally important, this measure of experience is also likely to mis-measure "effective" experience in the sample of immigrants-i.e., the number of years of work experience that are valued by an American employer. After all, a variable that roughly approximates "Age Education -6 " does not differentiate between experience acquired in the source country and experience acquired in the United States. I address this problem in Section VI below.

I assume that the age of entry into the labor market is 17 for the typical high school dropout, 19 for the typical high school graduate, 21 for the typical person with some college, and 
23 for the typical college graduate. Let $A_{T}$ be the assumed entry age for workers in a particular schooling group. The measure of work experience is then given by $\left(\right.$ Age $\left.-A_{T}\right)$. I restrict the analysis to persons who have between 1 and 40 years of experience.

As noted in Welch's [1979] study of the impact of cohort size on the earnings of baby boomers, workers in adjacent experience cells are more likely to influence each other's labor market opportunities than workers in cells that are further apart. Throughout much of the analysis, I will capture the similarity across workers with roughly similar years of experience by aggregating the data into five-year experience intervals, indicating if the worker has 1 to 5 years of experience, 6 to 10 years, and so on.

Consider a group of workers who have educational attainment $i$, experience level $j$, and are observed in calendar year $t$. The $(i, j, t)$ cell defines a skill group at a point in time. The measure of the immigrant supply shock for this skill group is defined by

$$
p_{i j t}=\frac{M_{i j t}}{\left(M_{i j t}+N_{i j t}\right)},
$$

where $M_{i j t}$ gives the number of immigrants in cell $(i, j, t)$, and $N_{i j t}$ gives the corresponding number of natives. The variable $p_{i j t}$ measures the foreign-born share of the labor force in a particular skill group.

The various panels of Figure I illustrate the supply shocks experienced by the different skill groups between 1960 and 2000 (Appendix 2 reports the underlying data). There is a great deal of dispersion in these shocks even within schooling categories. It is well known, for instance, that immigration greatly increased the supply of high school dropouts in recent decades. What is less well known, however, is that this supply shift did not affect equally all 
experience groups within the population of high school dropouts. Moreover, the imbalance in the supply shock changes over time. As Panel A of the figure shows, immigrants made up half of all high school dropouts with 10 to 20 years of experience in 2000 , but only 20 percent of those with less than 5 years. In 1960, however, the immigration of high school dropouts increased the supply of the most experienced workers the most. Similarly, Panel D shows that the immigrant supply shock for college graduates in 1990 was reasonably balanced across all experience groups, generally increasing supply by around 10 percent. But the supply shock for college graduates in 1960 was larger for the most experienced groups, while in 2000 it was largest for the groups with 5 to 20 years of experience.

The earnings data used in the paper are drawn from the sample of persons who worked in the year prior to the survey and reported positive annual earnings, are not enrolled in school, and are employed in the wage and salary sector. Earnings are deflated to 1999 dollars by using the CPI-U series. Table I summarizes the trends in log weekly wages for the various native groups. Not surprisingly, there is a great deal of dispersion in the rate of decadal wage growth by education and experience. Consider, for instance, the sample of college graduates. In the 1970s, wage growth was steepest for college graduates with 31-35 years of experience. In the 1990s, however, the wage of college graduates grew fastest for workers with 11-20 years of experience. In sum, the data reveal substantial variation in both the immigrant supply shock and native labor market outcomes across skill groups.

Before proceeding to a formal analysis, it is instructive to document the strong link that exists between log weekly wages and the immigrant share within schooling-experience cells. In particular, I use the data reported in Table I to calculate the decadal change in log weekly wages for each skill group, and the data summarized in the various panels of Figure I (and reported in Appendix 2) to calculate the decadal change in the group's immigrant share. Figure II presents 
the scatter diagram relating these decadal changes after removing decade effects from the differenced data. The plot clearly illustrates a negative relation between wage growth and immigrant penetration into particular skill groups, and suggests that the regression line is not being driven by any particular outliers. Put simply, the raw data show that weekly wages grew fastest for workers in those education-experience groups that were least affected by immigration.

Finally, the validity of the empirical exercise reported below hinges on the assumption that similarly educated workers who have different levels of experience are not perfect substitutes. Studies that examine this question, including Welch [1979] and Card and Lemieux [2001], find less than perfect substitutability across experience groups. Nevertheless, it is of interest to document that (for given education) immigrants and natives with similar levels of experience are closer substitutes than immigrants and natives who differ in their experience.

I use Welch's [1999] index of congruence to measure the degree of similarity in the occupation distributions of immigrants and natives. The index for any two skill groups $k$ and $\ell$ is defined by

$$
G_{k \ell}=\frac{\sum_{c}\left(q_{k c}-\bar{q}_{c}\right)\left(q_{\ell c}-\bar{q}_{c}\right) / \bar{q}_{c}}{\sqrt{\left(\sum_{c}\left(q_{k c}-\bar{q}_{c}\right)^{2} / \bar{q}_{c}\right)\left(\sum_{c}\left(q_{\ell c}-\bar{q}_{c}\right)^{2} / \bar{q}_{c}\right)}},
$$

where $q_{h c}$ gives the fraction of group $h(h=k, \ell)$ employed in occupation $c$, and $\bar{q}_{c}$ gives the fraction of the entire workforce employed in that occupation. The index $G_{k}$, which is similar to a correlation coefficient, equals one when the two groups have identical occupation distributions and minus one when the two groups are clustered in completely different occupations. 
I calculate the index of congruence in the 1990 Census. I use the three-digit Census Occupation Codes to classify male workers into the various occupations, and restrict the analysis to workers in non-military occupations. To minimize the problem of having many occupationexperience cells with few observations, I aggregate workers into 10-year experience bands. Table II reports the calculated indices for each of the education groups. The occupation distributions of immigrants and natives with the same experience are generally more similar than the distributions of immigrants and natives with different levels of experience. Moreover, the congruence index falls the larger the disparity in work experience between the two groups.

Consider the group of native workers who are high school dropouts and have 11 to 20 years of experience. The index of congruence with immigrants who have the same experience is 0.63. This index falls to 0.53 for immigrants who have 1 to 10 years of experience, and to 0.59 for immigrants with 31 to 40 years. Similarly, consider the native workers who are college graduates and have fewer than 10 years of experience. The index of congruence with immigrants who have the same experience is 0.76 , but this index falls to 0.71 for immigrants who have 11 to 20 years of experience, to 0.64 for immigrants who have 21 to 30 years, and to 0.53 for immigrants who have more than 30 years. In sum, the occupation distributions of immigrants and natives (for a given level of education) are most similar when one compares workers who have roughly the same level of work experience.

\section{Basic Results}

Let $y_{i j t}$ denote the mean value of a particular labor market outcome for native men who have education $i(i=1, \ldots, 4)$, experience $j(j=1, \ldots, 8)$, and are observed at time $t(t=1960$, 
1970, 1980, 1990, 2000). Much of the empirical analysis reported in this paper stacks these data across skill groups and calendar years and estimates the model: ${ }^{6}$

$$
y_{i j t}=\theta p_{i j t}+s_{i}+x_{j}+\pi_{t}+\left(s_{i} \times x_{j}\right)+\left(s_{i} \times \pi_{t}\right)+\left(x_{j} \times \pi_{t}\right)+\varphi_{i j t},
$$

where $s_{i}$ is a vector of fixed effects indicating the group's educational attainment; $x_{j}$ is a vector of fixed effects indicating the group's work experience; and $\pi_{t}$ is a vector of fixed effects indicating the time period. The linear fixed effects in equation (3) control for differences in labor market outcomes across schooling groups, experience groups, and over time. The interactions $\left(s_{i} \times \pi_{t}\right)$ and $\left(x_{j} \times \pi_{t}\right)$ control for the possibility that the impact of education and experience changed over time, and the interaction $\left(s_{i} \times x_{j}\right)$ controls for the fact that the experience profile for a particular labor market outcome differs across schooling groups.

The dependent variables are the mean of log annual earnings, the mean of log weekly earnings, and the mean of fraction of time worked (defined as weeks worked divided by 52 in the sample of all persons, including non-workers). Unless otherwise specified, the regressions are weighted by the sample size used to calculate $y_{i j t}$. The presence of the education-experience

${ }^{6}$ The generic regression of wages on some measure of immigrant penetration is used frequently in the literature. Suppose the labor demand function in the pre-immigration period is $\log w_{k t}=D_{k t}+\varepsilon \log N_{k t}+\varphi$, where $k$ is a skill group. The wage change resulting from an exogenous influx of immigrants is

$$
\Delta \log w_{k t}=\Delta D_{k t}+\varepsilon \log \left[\left(N_{k t}\left(1+n_{k t}\right)+M_{k t}\right) / N_{k t}\right]+\xi \approx \Delta D_{k t}+\varepsilon\left(n_{k t}+m_{k t}\right)+\xi,
$$

where $n_{k t}$ gives the percent change in the number of natives, and $m_{k t}=M_{k t} / N_{k t}$. The rate of change $n_{k t}$ is determined by the labor supply function, $n_{k t}=S_{k t}+\sigma \Delta \log w_{k t}+\mu$. The reduced-form wage equation is

$$
\Delta \log w_{k t}=X_{k t}+\varepsilon^{*} m_{k t}+\xi^{*},
$$

where $X_{k t}=\left(\Delta D_{k t}+\varepsilon S_{k t}\right) /(1-\varepsilon \sigma)$ and $\varepsilon^{*}=\varepsilon /(1-\varepsilon \sigma)$. Equation (3) is a transformation of this reduced-form equation that approximately uses $\log m_{k t}$, rather than $m_{k t}$, as the measure of immigrant penetration. In particular, log $m \approx(M-N) /(0.5(M+N))=2(2 p-1)$. I opted for the immigrant share specification because the relation between wages and $m$ is nonlinear and $m$ has a large variance both over time and across groups. 
interactions in (3) implies that the impact of immigration on labor market outcomes is identified from changes that occur within education-experience cells over time. The standard errors are clustered by education-experience cells to adjust for possible serial correlation.

The first row of Table III presents the basic estimates of the adjustment coefficient $\theta$. Consider initially the results when the dependent variable is the log of weekly earnings of native workers. The coefficient is -0.572 , with a standard error of 0.162 . It is easier to interpret this coefficient by converting it to an elasticity that gives the percent change in wages associated with a percent change in labor supply. Let $m_{i j t}=M_{i j t} / N_{i j t}$, or the percentage increase in the labor supply of group $(i, j, t)$ attributable to immigration. Define the "wage elasticity" as ${ }^{7}$

$$
\frac{\partial \log w_{i j t}}{\partial m_{i j t}}=\frac{\theta}{\left(1+m_{i j t}\right)^{2}} .
$$

By 2000 , immigration had increased the number of men in the labor force by 16.8 percent. Equation (4) implies that the wage elasticity—evaluated at the mean value of the immigrant supply increase — can be obtained by multiplying $\theta$ by approximately 0.7 . The wage elasticity for weekly earnings is then -0.40 (or $-0.572 \times 0.7$ ). Put differently, a 10 percent supply shock (i.e., an immigrant flow that increases the number of workers in the skill group by 10 percent) reduces weekly earnings by about 4 percent.

Table III indicates that immigration has an even stronger effect on annual earnings, suggesting that immigration reduces the labor supply of native male workers. A 10 percent

\footnotetext{
${ }^{7}$ As noted above, the immigrant share approximates $\log m$. Because there are no cells with zero immigrants in the data used in Table III, the results are virtually identical (once properly interpreted) if $\log m$ is used as the regressor. In the next section, however, where I categorize workers by state of residence, education, and experience, 15.7 percent of the cells have no immigrants, and using $\log m$ would create a serious selection problem.
} 
supply shock reduces annual earnings by 6.4 percent and the fraction of time worked by 3.7 percentage points. Note that the difference in the coefficients from the log annual earnings and the log weekly earnings regressions gives the coefficient from a log weeks worked specification. A simple supply-demand framework implies that the labor supply elasticity for workers can be estimated from the ratio of the immigration effect on log weeks worked and log weekly earnings. The point estimate for this ratio is 0.6 . This estimate lies above the range reported by Juhn, Murphy, and Topel [1991], who report labor supply elasticities between 0.1 and 0.4. ${ }^{8}$

The remaining rows of Table III conduct a variety of specification tests to determine the sensitivity of the results. The coefficients reported in the second row, for example, indicate that the results are similar when the regressions are not weighted by the sample size of the skill group. In the third row, the regression redefines the measure of the immigrant share $p_{i j t}$ to include both male and female labor force participants. Despite the misclassification of many women into the various experience groups, the adjustment coefficients remain negative and significant, and have similar values to those reported in the first row. The last row of the table addresses the interpretation problem that arises because a rise in $p_{i j t}$ can represent either an increase in the number of immigrants or a decline in the number of native workers in that skill group (e.g., the secular decline in the number of natives who are high school dropouts). Row 4 of the table reports the adjustment coefficient when the regression adds the log of the size of the native workforce in cell $(i, j, t)$ as a regressor. The wage elasticity for log weekly earnings is -0.39 and

\footnotetext{
8 The variable $p_{i j t}$ gives the immigrant share among labor force participants. The labor force participation decision may introduce some endogeneity in this variable. The problem can be addressed by using an instrument given by the immigrant share in the population of all men in cell $(i, j, t)$. The IV estimates of $\theta$ (and standard errors) are $-0.803(0.586)$ for log annual earnings, $-0.541(0.153)$ for log weekly earnings, and $-0.493(0.125)$ for the fraction of time worked. These coefficients are similar to those reported in the first row of Table III. The immigrant share may also be endogenous in a different sense. Suppose the labor market attracts foreign workers mainly in those skill cells where wages are relatively high. There would be a spurious positive correlation between $p_{i j t}$ and the wage. The results in Table III should then be interpreted as lower bounds of the true impact of immigration.
} 
significant. In short, the parameter $\theta$ in equation (3) is indeed capturing the impact of an increase in the size of the immigrant population on native labor market outcomes. ${ }^{9}$

I also estimated the regression model within schooling groups to determine if the results are being driven by particular groups, such as the large influx of foreign-born high school dropouts. With only one exception, Table IV shows that the impact of immigration on the weekly earnings of particular schooling groups is negative and significant. The exception is the group of college graduates, where the adjustment coefficient is positive and has a large standard error. Note, however, that the regression estimated within a schooling group cannot include experience-period interactions to control for secular changes in the shape of the experienceearnings profile. As a result, the coefficient of the immigrant share variable may be measuring a spurious correlation between immigration and factors that changed the wage structure differentially within schooling groups. It is probably not coincidental that the adjustment coefficient is positive for college graduates, the group that experienced perhaps the most striking change in the wage structure in recent decades. ${ }^{10}$

Finally, the last column of Table IV estimates the regressions using only the groups of natives with at least a high school education. The coefficients generally suggest that the sample of high school dropouts is not the group that is driving much of the analysis. Although the

\footnotetext{
9 The results would be roughly similar if the regressions were estimated separately using each set of two adjacent cross-sections, so that the regression models would be differencing the data over a decade. The adjustment coefficients (and standard errors) for log weekly earnings are: -1.042 (0.484) in 1960-1970, -0.427 (0.561) in 1970$1980,-0.277(0.480)$ in $1980-1990$, and $-0.285(0.270)$ in $1990-2000$. This rough similarity contrasts with the inability of the spatial correlation approach to generate parameter estimates that even have the same sign over time; see Borjas, Freeman, and Katz [1997] and Schoeni [1997].

${ }^{10}$ I also estimated the regression model within experience groups. The adjustment coefficients (and standard errors) for log weekly earnings were: $1-5$ years of experience, $-0.403(0.470)$; $6-10$ years, $-0.358(0.286)$; $11-15$ years; $-0.475(0.285)$; $16-20$ years, $-0.555(0.244)$; $21-25$ years, $-0.568(0.244)$; $26-30$ years, $-0.634(0.193)$; $31-35$ years, $-0.495(0.288)$; and $36-40$ years, $-0.147(0.228)$. Although these regressions only have 20 observations, the point estimate of $\theta$ is negative and significant for many groups.
} 
adjustment coefficients remain negative for all the dependent variables, it is insignificant for log weekly earnings. In the case of $\log$ annual earnings, however, the wage elasticity is around -0.8 , suggesting that immigration had an adverse impact on native workers even when the regression ignores the information provided by the workers who experienced the largest supply shock in the past few decades. ${ }^{11}$

\section{A Comparison with the Spatial Correlation Approach}

In contrast to the studies that calculate spatial correlations between wages in local labor markets and measures of immigrant penetration, the evidence presented in the previous section indicates that immigrants have a sizable adverse effect on the wage of competing workers. This discrepancy suggests that it might be instructive to examine how the results of the generic spatial correlation regression would change if that analysis defined skill groups in terms of both education and experience.

Suppose that the relevant labor market for a typical worker is determined by his state of residence $(r)$, education, and experience. ${ }^{12}$ I use the 1960-2000 Census and CPS files to calculate both the immigrant share and the mean labor market outcomes for cell $(r, i, j, t)$. I then use these

\footnotetext{
${ }^{11}$ It is of interest to use the labor market outcomes of immigrants as the dependent variable. I used the sample of immigrants with fewer than 30 years of experience because there are relatively few observations in the cells for older workers in 1970 and 2000; and did not use data from the 1960 Census because that survey does not provide information on the immigrant's year of entry into the United States. The estimates are imprecise, but the results resemble those found for native workers once I control for cohort and assimilation effects. If the regression is estimated on the sample of immigrants who have been in the United States for fewer than 10 years, the adjustment coefficients (and standard errors) are $-0.506(0.398)$ for log annual earnings, $-0.290(0.350)$ for log weekly earnings, and $-0.192(0.105)$ for the fraction of time worked.

12 I use states to define the geographic boundary of the labor market because a worker's state of residence is the only geographic variable that is consistently coded across the entire 1960-2000 span. The 1960 Census does not report the person's metropolitan area of residence, and the metropolitan area identifiers for the 1970 Census differ substantially from those reported in later surveys.
} 
aggregate data to estimate regressions similar to those presented above, but the unit of analysis is now a state-education-experience group at a particular point in time.

Table $\mathrm{V}$ reports the estimated coefficient of the immigrant share variable from this regression framework. The first column of the table presents the coefficient from the simplest specification, which includes the state, education, experience, and period fixed effects, as well as interactions between the state, education, and experience fixed effects with the vector of period fixed effects, and interactions between the state and education fixed effects. This regression, in effect, estimates the impact of immigration on the change in labor market outcomes experienced by a particular education group in a particular state. The adjustment coefficients for the various dependent variables are negative and mostly significant. The adjustment coefficient in the log weekly earnings regression is -0.124 , with a standard error of 0.042 . Note that the implied adverse impact of immigration resulting from this specification is far smaller than the effects reported in the previous section.

The second column of Table $\mathrm{V}$ adds a three-way interaction between the state, education, and experience fixed effects. This specification, therefore, examines the impact of immigration on the wage growth experienced by a particular education-experience group living in a particular state. The adjustment coefficients are more negative $(-0.217$ in the log weekly wage specification) and statistically significant. In short, defining a skill group in terms of both education and experience implies that immigration has a more adverse impact than a specification that ignores the experience component.

The third column of the table further expands the model by allowing for period effects to vary across education-experience cells, while the fourth column presents the full specification of the regression that allows for all possible three-way interactions between the state, education, experience, and period fixed effects. This regression specification effectively identifies the wage 
impact by using only variation in immigration at the (state $\times$ education $\times$ experience $\times$ period)

level. The coefficient is negative and significant (-0.183 in the log weekly wage specification), and it is numerically much smaller than the coefficients reported in the previous section.

In fact, it is instructive to contrast the difference in the results reported in the last column of Table V with the evidence reported in Table III. The key difference between the two sets of estimates is the assumption made about the geographic boundary of the labor market. The estimated wage elasticity for log weekly earnings is -0.13 when a state's geographic boundary limits the size of the market, and -0.40 when the worker participates in a national market. One interesting interpretation of this discrepancy is that there is sufficient spatial arbitrage—perhaps due to interstate flows of labor and capital — that tends to equalize opportunities for workers of given skills across regions. The spatial arbitrage effectively cuts the national estimate of the impact of immigration by two-thirds. ${ }^{13}$ Put differently, even though immigration has a sizable adverse effect on the wage of competing workers at the national level, the analysis of wage differentials across regional labor markets conceals much of the impact.

\section{Refining the Definition of Skills}

\section{A. Measuring Effective Experience}

\footnotetext{
13 The smaller wage effects estimated at the state level could also be due to attenuation bias from the measurement error that arises when I calculate the immigrant supply shock at such a detailed level of disaggregation. I reestimated the model using the nine Census regions (rather than states) as the geographic unit. The region-level regression coefficients corresponding to the last column of Table V are -.346 (.096) in the log annual earnings regression; -.289 (.070) in the log weekly earnings regression; and -.057 (.023) in the fraction of time worked regression. Even though the coefficients in the annual and weekly earnings regressions are numerically larger than those obtained in the state-level analysis, the coefficient in the log weekly earnings regression is still only half the size of the one reported in Table III. Moreover, it is unclear if the relatively larger effects estimated at the region level result from the partial elimination of attenuation bias or from the possibility that some of the native flows induced by immigration are intra-regional, and hence the region is a slightly better conceptual representation of the "closed market" required for measuring the local impact of immigration; see Borjas, Freeman, and Katz [1996] for related evidence.
} 
Up to this point, labor market experience has been defined as the time elapsed since entry into the labor market for both immigrants and natives. The evidence indicates that U.S. firms attach different values to experience acquired abroad and experience acquired in the United States [Chiswick 1978]. These findings suggest that one should use the "effective experience" of an immigrant worker before assigning that worker to a particular schooling-experience group, where effective experience measures the years of work exposure that are valued in the U.S. labor market. Let $A$ denote age, $A_{m}$ the age of entry into the United States, and $A_{T}$ the age of entry into the labor market. The years of effective experience for an immigrant worker are given by

$$
X= \begin{cases}\alpha\left(A_{M}-A_{T}\right)+\beta\left(A-A_{m}\right), & \text { if } A_{m}>A_{T} \\ \gamma\left(A-A_{T}\right), & \text { if } A_{m} \leq A_{T},\end{cases}
$$

where $\alpha$ translates a year of source country experience acquired by immigrants who migrated as adults (i.e., $A_{m}>A_{T}$ ) into the equivalent value of experience acquired by a native worker; $\beta$ rescales the value of a year of U.S. experience acquired by these adult immigrants; and $\gamma$ rescales the experience acquired by immigrants who migrated as children (i.e., $A_{m} \leq A_{T}$ ).

The parameters $\alpha, \beta$, and $\gamma$ can be estimated by using the standard model of immigrant assimilation, a model that also accounts for differences in immigrant "quality" across cohorts [Borjas 1985]. Suppose we pool data for native and immigrant workers in two separate crosssections (such as the 1980 and 1990 Censuses). A generic regression model that can identify all of the relevant parameters is

$$
\begin{aligned}
\log w & =s_{i}+\phi_{C} I^{C}+\phi_{D} I^{D}+\lambda_{N} N\left(A-A_{T}\right)+\lambda_{C} I^{C}\left(A-A_{T}\right) \\
& +\lambda_{D 0} I^{D}\left(A_{m}-A_{T}\right)+\lambda_{D 1} I^{D}\left(A-A_{m}\right)+\kappa Y+\rho \pi+\varphi,
\end{aligned}
$$


where $w$ gives the weekly wage of a worker observed in a particular cross-section; $s_{i}$ gives a vector of education fixed effects; $I^{C}$ indicates if the immigrant entered the country as a child; $I^{D}$ indicates if the immigrant entered as an adult; $N$ indicates if the worker is native-born $(N=1-$ $I^{C}-I^{D}$ ); $Y$ gives the calendar year of entry into the United States (set to zero for natives); and $\pi$ indicates if the observation is drawn from the 1990 Census.

The coefficient $\lambda_{N}$ gives the market value of a year of experience acquired by a native worker; $\lambda_{C}$ gives the value of a year of experience acquired in the United States by a "child immigrant"; and $\lambda_{D 0}$ and $\lambda_{D 1}$ give the value of a year of source country experience and of U.S. experience acquired by an adult immigrant, respectively. The weights that define an immigrant's effective experience are

$$
\alpha=\frac{\lambda_{D 0}}{\lambda_{N}}, \quad \beta=\frac{\lambda_{D 1}}{\lambda_{N}}, \quad \gamma=\frac{\lambda_{C}}{\lambda_{N}} .
$$

Although the generic regression model in (6) is pedagogically useful, it ignores the curvature of the experience-earnings profile, and also ignores the possibility that the returns to education differ among the various groups. Further, it is preferable to define the calendar year of an immigrant's arrival as a vector of dummy variables indicating the year of arrival, rather than as a linear time trend. I estimated this more general model using the pooled 1980 and 1990 data. Table VI reports the relevant coefficients from this regression.

The experience coefficients for natives and for immigrants who migrated as children have almost identical numerical values, so that a marginal year of experience is valued at the same rate by employers (although the tiny numerical difference is statistically significant). This 
implies that the weight $\gamma$ is estimated to be 1.0. In contrast, the value of an additional year of source country experience for adult immigrants (evaluated at the mean years of source country experience) is 0.006 , while the value of an additional year of U.S. experience for these immigrants is 0.024 . The value of a year of experience for a comparable native worker is 0.015 . The implied weights are $\alpha=0.4$ and $\beta=1.6$.

I used these weights to calculate the effective experience of each immigrant, and then reclassified them into the schooling-experience cells using the predicted measure of effective experience. ${ }^{14}$ The top row of Table VII reports the estimated adjustment coefficients. The effects are roughly similar to those reported in the previous section. For example, the weekly earnings regression implies that the wage elasticity is -.30 , and the effect is statistically significant.

\section{B. Measuring Effective Skills}

The notion of effective experience raises a more general question about the overall comparability of the skills of immigrants and natives. The U.S. labor market differentiates the value of human capital embodied in immigrants and natives along many dimensions. For example, the value that firms attach to schooling will probably differ between the two groups, as well as among immigrants originating in different countries. It is of interest, therefore, to devise a simple way of summarizing the differences in "effective skills" that exist between immigrants and natives within a schooling category. It seems sensible to assume that similarly educated workers who fall in the same general location of the wage distribution have roughly the same

\footnotetext{
${ }^{14}$ Neither the Census nor the CPS report the exact year in which immigrants entered the United States, but instead report the year of entry within particular intervals (e.g., 1980-84). I used a uniform distribution to randomly assign workers in each interval to each year in the interval. Because the immigrant's year of arrival is not reported in the 1960 Census, the analysis is restricted to data drawn from the 1970 through 2000 cross-sections.
} 
number of efficiency units because employers attach the same value to the entire package of skills embodied in these workers.

To conduct this classification of workers into skill groups, I restrict the analysis to workers who have valid wage data. In each cross-section and for each of the four schooling groups, I sliced the weekly wage distribution of native workers into 20 quantiles. By construction, five percent of natives in each schooling group fall into each of the quantiles. I then calculated how many of the immigrant workers in each schooling group fall into each of the 20 quantiles. The immigrant supply shock is defined by

$$
\hat{p}_{i k t}=\frac{M_{i k t}}{\left(M_{i k t}+N_{i k t}\right)},
$$

where $M_{i k t}$ and $N_{i k t}$ give the number of foreign-born and native-born workers in schooling group $i$, quantile $k(k=1, \ldots, 20)$, at time $t$.

Consider the regression model:

$$
y_{i k t}=\theta \hat{p}_{i k t}+s_{i}+q_{k}+\pi_{t}+\left(q_{k} \times s_{i}\right)+\left(s_{i} \times \pi_{t}\right)+\left(q_{k} \times \pi_{t}\right)+\varphi_{i k t},
$$

where $q_{k}$ is a vector of fixed effects indicating the quantile of the cell. The second row of Table VII reports the adjustment coefficients estimated from this specification of the model. Despite the very different methodological approach employed to define the skill groups, the estimated coefficient in the log weekly earnings regression is similar to those reported above. The estimate of $\theta$ is -0.606 (with a standard error of 0.158 ), implying a wage elasticity of -0.42 . In sum, the evidence suggests that the clustering of immigrants into particular segments of the wage 
distribution worsened the wage outcomes of native workers who happened to reside in those regions of the wage distribution. ${ }^{15}$

\section{A Structural Approach to Immigration and Factor Demand}

\section{A. Theory and Evidence}

Up to this point, I have not imposed any economic structure in the estimation of the wage effects of immigration. As in most of the studies in the spatial correlation literature, I have instead attempted to calculate the correlation that indicates if an increase in the number of immigrants lowers the wage of competing native workers.

An alternative approach would impose more structure by specifying the technology of the aggregate production function. ${ }^{16}$ This structural approach would make it possible to estimate not only the effect of a particular immigrant influx on the wage of competing native workers, but also the cross-effects on the wage of other natives. An empirically useful approach assumes that the aggregate production function can be represented in terms of a three-level CES technology: Similarly educated workers with different levels of work experience are aggregated to form the

15 The fraction of time worked variable used in the regression reported in the second row of Table VII has a different definition than elsewhere in this paper. To simplify the sorting of persons into the quantiles of the wage distribution, I restricted the analysis to working men. One could classify non-workers into the various quantiles by using a first-stage regression that predicts earnings based on a person's educational attainment, experience, and other variables. For native men, this approach leads to results that are similar to those reported in the text.

16 Early empirical studies of the labor market impact of immigration [Grossman 1982; Borjas 1987] actually imposed a structure on the technology of the local labor market, such as the translog or the Generalized Leontief, and used the resulting estimates to calculate the various substitution elasticities. Although this approach fell out of favor in the early 1990s, the evidence reported by Card [2001] and the results presented in this section suggest that the structural approach may be due for a timely comeback. 
effective supply of an education group; and workers across education groups are then aggregated to form the national workforce. ${ }^{17}$

Suppose the aggregate production function for the national economy at time $t$ is

$$
Q_{t}=\left[\lambda_{K t} K_{t}^{v}+\lambda_{L t} L_{t}^{v}\right]^{1 / v}
$$

where $Q$ is output, $K$ is capital, $L$ denotes the aggregate labor input; and $v=1-1 / \sigma_{K L}$, with $\sigma_{K L}$ being the elasticity of substitution between capital and labor $(-\infty<v \leq 1)$. The vector $\lambda$ gives time-variant technology parameters that shift the production frontier, with $\lambda_{K t}+\lambda_{L t}=1$. The aggregate $L_{t}$ incorporates the contributions of workers who differ in both education and experience. Let

$$
L_{t}=\left[\sum_{i} \theta_{i t} L_{i t}^{\rho}\right]^{1 / \rho},
$$

where $L_{i t}$ gives the number of workers with education $i$ at time $t$, and $\rho=1-1 / \sigma_{E}$, with $\sigma_{E}$ being the elasticity of substitution across these education aggregates $(-\infty<\rho \leq 1)$. The $\theta_{i t}$ give timevariant technology parameters that shift the relative productivity of education groups, with $\Sigma_{i} \theta_{i t}$ $=1$. Finally, the supply of workers in each education group is itself given by an aggregation of the contribution of similarly educated workers with different experience. In particular,

17 The three-level CES technology slightly generalizes the two-level approach used in the labor demand context by Bowles [1970] and Card and Lemieux [2001]. 


$$
L_{i t}=\left[\sum_{j} \alpha_{i j} L_{i j t}^{\eta}\right]^{1 / \eta},
$$

where $L_{i j t}$ gives the number of workers in education group $i$ and experience group $j$ at time $t$; and $\eta=1-1 / \sigma_{X}$, with $\sigma_{X}$ being the elasticity of substitution across experience classes within an education group $(-\infty<\eta \leq 1)$. Equation (12) incorporates an important identifying assumption: the technology coefficients $\alpha_{i j}$ are constant over time, with $\Sigma_{j} \alpha_{i j}=1$.

The marginal productivity condition implies that the wage for skill group $(i, j, t)$ is

$$
\begin{aligned}
\log w_{i j t} & =\log \lambda_{L t}+(1-v) \log Q_{t}+(v-\rho) \log L_{\mathrm{t}}+\log \theta_{i t}+(\rho-\eta) \log L_{i t} \\
& +\log \alpha_{i j}+(\eta-1) \log L_{i j t} .
\end{aligned}
$$

As Card and Lemieux [2001] show in their recent study of the link between the wage structure and cohort size, it is straightforward to implement this approach empirically. In particular, note that the marginal productivity condition in (13) can be rewritten as

$$
\log w_{i j t}=\delta_{t}+\delta_{i t}+\delta_{i j}-\frac{1}{\sigma_{X}} \log L_{i j t}
$$

where $\delta_{t}=\log \lambda_{L t}+(1-v) \log Q_{t}+(v-\rho) \log L_{t}$, and is absorbed by period fixed effects; $\delta_{i t}=$ $\log \theta_{i t}+(\rho-\eta) \log L_{i t}$ and is absorbed by interactions between the education fixed effects and the period fixed effects; and $\delta_{i j}=\log \alpha_{i j}$, and is absorbed by interactions between education fixed 
effects and experience fixed effects. The regression model in (14), therefore, identifies the elasticity of substitution across experience groups.

Moreover, the coefficients of the education-experience interactions in (14) identify the parameters $\log \alpha_{i j}$. I impose the restriction that $\Sigma_{j} \alpha_{i j}=1$ when I estimate the $\alpha_{i j}$ from the fixed effect coefficients. ${ }^{18}$ As indicated by equation (12), the estimates of $\alpha_{i j}$ and $\sigma_{X}$ permit the calculation of $L_{i t}$, the CES-weighted labor aggregate for education group $i$. I can then move up one level in the CES technology, and recover an additional unknown parameter. Let $\log w_{i t}$ be the mean log wage paid to the average worker in education group $i$ at time $t$. The marginal productivity condition determining the wage for this group is

$$
\log w_{i t}=\delta_{t}+\log \theta_{i t}-\frac{1}{\sigma_{E}} \log L_{i t} .
$$

This equation is closely related to the model estimated by Katz and Murphy [1992, p. 69] that examines how the wage differential between college and high school graduates varies with relative supplies. Note that $\sigma_{E}$ cannot be identified if the regression included interactions of education-period fixed effects to capture the term $\log \theta_{i t}$. There would be 20 such interaction terms, but there are only 20 observations in the regression (four education groups observed at five different points in time). To identify $\sigma_{E}$, I adopt the Katz-Murphy assumption that the technology shifters can be approximated by a linear trend that varies across education groups.

It is important to note that ordinary least squares regressions of equations (14) and (15) may lead to biased estimates of $\sigma_{X}$ and $\sigma_{\ddot{E}}$ because the supply of workers to the various education

\footnotetext{
18 If $\log \hat{\alpha}_{i j}$ is an estimated fixed effect coefficient, then $\hat{\alpha}_{i j}=\exp \left(\log \hat{\alpha}_{i j}\right) / \sum_{j} \exp \left(\log \hat{\alpha}_{i j}\right)$.
} 
groups is likely to be endogenous over the 40 -year period spanned by the data. The economic question at the core of this paper, however, suggests an instrument for the size of the workforce in each skill group: the number of immigrants in that group. In other words, the immigrant influx into particular skill groups provides the supply shifter required to identify the labor demand function. This instrument would be valid if the immigrant influx into particular skill groups were independent of the relative wages offered to the various skill categories. It is likely, however, that the number of immigrants in a skill group responds to shifts in the wage structure. Incomemaximizing behavior on the part of potential immigrants would generate larger flows into those skill cells that had relatively high wages. This behavioral response would tend to build in a positive correlation between the size of the labor force and wages in a skill group. The regression coefficients, therefore, understate the negative wage impact of a relative supply increase. ${ }^{19}$

The three-level CES technology offers a crucial advantage for estimating the impact of immigration within a structural system of factor demand. My analysis defines 33 factors of production: 32 education-experience skill groups plus capital. A general specification of the technology, such as the translog, would require the estimation of 561 different parameters (or $n(n+1) / 2)$. The three-level CES approach drastically reduces the size of the parameter space; the technology can be summarized in terms of three elasticities of substitution. Obviously, this simplification comes at a cost: the CES specification restricts the types of substitution that can

${ }^{19}$ Consider the regression model given by $\log w=\beta \log L+u$. The IV estimate of $\beta$ has the property:

$$
\operatorname{plim} \hat{\beta}=\beta+\frac{\operatorname{cov}(\log M, u)}{\operatorname{cov}(\log M, \log L)},
$$

where $\log M$ is the instrument. The total number of workers in a skill group is, in fact, positively correlated with the number of immigrants in that group, so that $\operatorname{cov}(\log M, \log L)>0$. Further, $\operatorname{cov}(\log M, u)>0$ because skill cells with 
exist among the various factors. The elasticity of substitution across experience groups takes on the same value for workers in adjacent experience categories as for workers who differ greatly in their experience; the elasticity of substitution between high school dropouts and high school graduates is the same as that between high school dropouts and college graduates; and the elasticity of substitution between capital and labor is the same for all the different types of workers.

Finally, note that the empirical implementation of the three-level CES technology described above does not use any data on the aggregate capital stock, making it difficult to separately identify the value of $\sigma_{K L} \cdot{ }^{20} \mathrm{I}$ will discuss below a plausible assumption that can be made about this parameter to simulate the impact of immigration on the labor market.

The first step in the empirical application of the model is to estimate equation (14) using the sample of $160(i, j, t)$ cells. The IV estimate of this regression equation is ${ }^{21}$

$$
\log w_{i j t}=\delta_{t}+\delta_{i t}+\delta_{i j}-0.288 \log L_{i j t} .
$$

favorable demand shocks will probably attract larger numbers of income-maximizing immigrants. The IV regression coefficient then provides a lower bound for the wage reduction resulting from a supply increase.

${ }^{20}$ In principle, the elasticity $\sigma_{K L}$ could be estimated even without direct information on the aggregate capital stock by going up an additional level in the CES hierarchy. This exercise yields the marginal productivity condition for the average worker at time $t$. This marginal productivity condition depends on a time fixed effect and on $L_{t}$, the CES-weighted aggregate of the workforce. The coefficient of $L_{t}$ identifies $-1 / \sigma_{K L}$. However, this regression would only have five observations in my data, and I would need to find a variable that could proxy for the movements in the period fixed effects.

21 The instrument is $\log M_{i j t}$ and the standard errors are clustered by education-experience group. To avoid introducing errors due to composition effects, the regressions reported in this section use the mean log weekly wage of native workers as the dependent variable. The results would be very similar if the mean log wage was calculated in the pooled sample of natives and immigrants. The relevant coefficients (and standard errors) in equations (16), (17), and (17') would be $-0.281(0.059),-0.676(0.518)$, and $-0.680(0.462)$, respectively. The regressions estimated in this section are weighted by the size of the sample used to calculate the cell mean on the left-hand-side. 
The implied elasticity of substitution across experience groups is 3.5. This estimate of $\sigma_{X}$ is similar to the Card-Lemieux [2001] estimate of the elasticity of substitution across age groups. The Card-Lemieux estimates for U.S. data range from 3.8 to 4.9.

I use the implied estimate of the elasticity of substitution and the (transformed) coefficients of the education-experience fixed effects to calculate the size of the CES-weighted labor aggregate for each education group. I then estimate the marginal productivity condition for the education group given by (15). The IV regression estimate is ${ }^{22}$

$$
\log w_{i t}=\delta_{t}+\text { linear trend interacted with education fixed effects }-0.741 \log L_{i t} \text {. }
$$

Alternatively, I can bypass the calculation of the CES-weighted labor aggregate for each education group, and simply use the actual number of workers in the group $\left(L_{i t}^{*}\right)$. The IV regression estimate is

$$
\log w_{i t}=\delta_{t}+\text { linear trend interacted with education fixed effects }-0.759 \log L_{i t}^{*} \text {. }
$$

Both specifications imply that $\sigma_{E}$ is around 1.3. The regressions reported in (17) and (17') have only 20 observations (four education groups observed at five different points in time), so that the elasticity of substitution is not measured precisely. Nevertheless, the implied elasticity is similar

\footnotetext{
22 The "linear trend interacted with education fixed effects" vector includes the linear trend and education fixed effects, as well as the interactions. The instrument in (17) is $\log M_{i t}$, where $M_{i t}=\left[\sum_{j} \alpha_{i j} M_{i j t}^{\eta}\right]^{1 / \eta}$. The alternative specification in $\left(17^{\prime}\right)$ uses the instrument $\log M_{i j t}^{*}$, where $M_{i t}^{*}=\sum_{j} M_{i j t}$.
} 
to the Katz-Murphy [1992] estimate of 1.4, despite the different data and methodology. ${ }^{23}$ In sum, the evidence indicates that workers within an experience group are not perfect substitutes, but there is clearly more substitution among similarly educated workers who differ in their experience than among workers with different levels of education.

\section{B. Simulating the Wage Effects of Immigration}

Hamermesh [1993, p. 37] shows that the factor price elasticity giving the impact on the wage of factor $y$ of an increase in the supply of factor $z$ is ${ }^{24}$

$$
\varepsilon_{y z}=\frac{d \log w_{y}}{d \log L_{z}}=s_{z} \frac{Q_{y z} Q}{Q_{y} Q_{z}} .
$$

where $s_{z}$ is the share of income accruing to factor $z$; and $Q_{y}=\partial Q / \partial L_{y}, Q_{z}=\partial Q / \partial L_{z}$, and $Q_{y z}=$ $\partial^{2} Q / \partial L_{y} \partial L_{z}$

The three-level CES technology implies that the own factor price elasticity giving the wage impact of an increase in the supply of workers with education $i$ and experience $j$ is

$$
\varepsilon_{i j, i j}=-\frac{1}{\sigma_{X}}+\left(\frac{1}{\sigma_{X}}-\frac{1}{\sigma_{E}}\right) \frac{s_{i j}}{s_{i}}+\left(\frac{1}{\sigma_{E}}-\frac{1}{\sigma_{K L}}\right) \frac{s_{i j}}{s_{L}}+\frac{1}{\sigma_{K L}} s_{i j},
$$

23 Card and Lemieux [2001] estimate the elasticity of substitution between high school and college equivalents to be between 1.1 and 3.1, depending on the sample composition.

24 The factor price elasticity holds marginal cost and the quantities of other factors constant. 
where $s_{i j}$ gives the share of income accruing to group $(i, j) ; s_{i}$ gives the share of income accruing to education group $i$; and $s_{L}$ gives labor's share of income. Similarly, the (within-branch) cross factor price elasticity giving the impact on the wage of group $(i, j)$ of an increase in the supply of group $\left(i, j^{\prime}\right)$, with $j \neq j^{\prime}$, is

$$
\varepsilon_{i j, i j^{\prime}}=\left(\frac{1}{\sigma_{X}}-\frac{1}{\sigma_{E}}\right) \frac{s_{i j^{\prime}}}{s_{i}}+\left(\frac{1}{\sigma_{E}}-\frac{1}{\sigma_{K L}}\right) \frac{s_{i j^{\prime}}}{s_{L}}+\frac{1}{\sigma_{K L}} s_{i j^{\prime}} .
$$

Finally, the (across-branch) cross factor price elasticity giving the impact on the wage of group $(i, j)$ of an increase in the supply of group $\left(i^{\prime}, j^{\prime}\right)$, with $i \neq i^{\prime}$ and $j^{\prime}=(1, \ldots, j, \ldots 8)$, is

$$
\varepsilon_{i j, i^{\prime} j^{\prime}}=\left(\frac{1}{\sigma_{E}}-\frac{1}{\sigma_{K L}}\right) \frac{s_{i^{\prime} j^{\prime}}}{S_{L}}+\frac{1}{\sigma_{K L}} S_{i^{\prime} j^{\prime}} .
$$

The calculations of the factor price elasticities in (19)-(21) require information on the factor shares. I assume that labor's share of income is 0.7 , and use the 1990 Census to calculate the share of total annual earnings accruing to each education-experience cell. I use these total annual earnings to apportion the labor shares accruing to the various groups. ${ }^{25}$ Based on the coefficients estimated above, I set $\sigma_{X}=3.5$ and $\sigma_{E}=1.3$. Finally, the calculations require an

${ }^{25}$ My calculation of the cell's income share uses all men and women who reported annual earnings in 1989. The estimated shares for the 8 experience groups within each education group are: high school dropouts $(0.003,0.004,0.006,0.005,0.005,0.007,0.007,0.007)$; high school graduates $(0.018,0.030,0.034,0.030,0.028$, $0.026,0.022,0.017)$; some college $(0.018,0.030,0.036,0.036,0.030,0.022,0.016,0.011)$; and college graduates $(0.025,0.039,0.044,0.049,0.037,0.025,0.019,0.013)$. These income shares, when aggregated to the level of the education group, are similar to the shares reported by Autor, Katz, and Krueger [1998, p. 1209]. The share of income accruing to high school dropouts is 4.5 percent; high school graduates, 20.5 percent; workers with some college, 19.9 percent; and college graduates, 25.1 percent. 
assumption about $\sigma_{K L}$. Hamermesh [1993, p. 92] concludes that the aggregate U.S. economy can be reasonably described by a Cobb-Douglas production function, suggesting that $\sigma_{K L}$ equals one. I impose this restriction in the analysis.

Table VIII reports the estimated elasticities. The own elasticity varies from -0.30 to -0.36 , with a weighted mean of -0.33 (where the weight is the size of the native labor force as of 2000). ${ }^{26}$ The table also reports the cross-elasticities within an education branch. Without exception, these cross-elasticities are negative and their weighted mean is -0.05 . Finally, the table reports the cross-elasticities across education branches. These cross-elasticities are positive and small, with a weighted mean of 0.02 . It is worth noting that the cross-branch elasticities reported for high school dropouts are very close to zero. This result follows from the definition of the elasticity in equation (21). Because the share of income accruing to high school dropouts is small, an influx of low-skill immigrants is bound to have only a tiny impact on the wage of workers in other education groups. ${ }^{27}$ As an example, consider the wage effects of a 10 percent increase in the number of college graduates who have 16-20 years of experience. The elasticities calculated for this group indicate that their own wage would drop by 3.5 percent; that the wage of other college graduates (with different levels of experience) would fall by -0.6 percent, and that the wage of all workers without a college degree would rise by 0.3 percent.

\footnotetext{
26 The own elasticities reported in Table VIII are not directly comparable to the "wage elasticities" reported earlier. As noted in footnote 6, the regression model estimated in previous sections identifies the reduced-form effect of immigration on wages. This reduced form effect is $\varepsilon /(1-\varepsilon \sigma)$, where $\varepsilon$ is the factor price elasticity and $\sigma$ is the labor supply elasticity. If $\varepsilon=-0.33$ and $\sigma=0.4$, for example, the implied reduced-form effect estimated in this section is -0.29 , which is somewhat smaller than the estimates that do not use a structural approach.

27 Murphy and Welch [1992] report elasticities of complementarity (defined as $Q_{y z} Q / Q_{y} Q_{z}$ ) for a number of education-experience groups. In the Murphy-Welch exercise, the cross-elasticities between high school graduates and college graduates tend to be positive, but the within-branch elasticities for a given education group are not always negative.
} 
I use the elasticity estimates reported in Table VIII to calculate the wage impact of the immigrant influx that entered the United States between 1980 and 2000. The marginal productivity condition for the typical worker in education group $s$ and experience group $x$ can be written as $w_{s x}=D\left(K, L_{11}, \ldots, L_{18}, \ldots, L_{41}, \ldots, L_{48}\right)$. Assuming that the capital stock is constant, the net impact of immigration on the log wage of group $(s, x)$ is 28

$$
\Delta \log w_{s x}=\varepsilon_{s x, s x} m_{s x}+\sum_{j \neq x} \varepsilon_{s x, s j} m_{s j}+\sum_{i \neq s} \sum_{j} \varepsilon_{s x, i j} m_{i j}
$$

where $m_{i j}$ gives the percentage change in labor supply due to immigration in cell $(i, j)$. Because the size of the native labor force in each skill group is shifting over time, I define $m_{i j}$ as

$$
m_{i j}=\frac{M_{i j, 2000}-M_{i j, 1980}}{0.5\left(N_{i j, 1980}+N_{i j, 2000}\right)+M_{i j, 1980}},
$$

so that the baseline population used to calculate the percent increase in labor supply averages out the size of the native workforce in the skill cell and treats the pre-existing immigrant population as part of the "native" stock.

Table IX summarizes the results of the simulation. The large immigrant influx of the 1980s and 1990s adversely affected the wage of most native workers, particularly those workers at the bottom and top of the education distribution. The wage fell by 8.9 percent for high school dropouts and by 4.9 percent for college graduates. In contrast, the wage of high school graduates

\footnotetext{
28 The assumption of a constant capital stock implies that the resulting wage consequences should be interpreted as short-run impacts. Over time, the changes in factor prices will fuel adjustments in the capital stock that attenuate the wage effects.
} 
fell by only 2.6 percent, while the wage of workers with some college was barely affected. Overall, the immigrant influx reduced the wage of the average native worker by 3.2 percent. These predictions assume that the elasticity of substitution between capital and labor equals one. Equations (19)-(21) imply that the adverse wage effects of immigration are larger if there is less substitution between capital and labor than implied by the aggregate Cobb-Douglas specification. For example, the predicted wage effect for each skill group is about one percentage point lower (i.e., more negative) when $\sigma_{K L}=0.75$, so that the wage of the average native worker would then fall by 4.2 percent.

\section{Conclusion}

The concern over the adverse labor market impact of immigration has always played a central role in the immigration debate. The resurgence of large-scale immigration in recent decades stimulated a great deal of research that attempts to measure these labor market effects. This research effort, based mainly on comparing native employment opportunities across regions, has not been entirely successful. The weak spatial correlations typically estimated in these studies, although often construed as showing that immigrants do not lower native wages, are difficult to interpret. In fact, economic theory implies that the more that firms and workers adjust to the immigrant supply shock, the smaller these cross-region correlations will beregardless of the true impact of immigration on the national economy.

This paper introduces a new approach for estimating the labor market impact of immigration. The analysis builds on the assumption that similarly educated workers who have different levels of experience are not perfect substitutes. Defining skill groups in terms of educational attainment and work experience introduces a great deal of variation in the data. In 
some years, the influx of immigrant with a particular level of schooling mainly affects younger workers, in other years it mainly affects older workers. In contrast to the existing literature, the evidence reported in this paper consistently indicates that immigration reduces the wage and labor supply of competing native workers, as suggested by the simplest textbook model of a competitive labor market. Moreover, the evidence indicates that spatial correlations conceal around two-thirds of the national impact of immigration on wages.

My estimates of the own factor price elasticity cluster between -0.3 and -0.4 . These estimates, combined with the very large immigrant influx in recent decades, imply that immigration has substantially worsened the labor market opportunities faced by many native workers. Between 1980 and 2000, immigration increased the labor supply of working men by 11.0 percent. Even after accounting for the beneficial cross-effects of low-skill (high-skill) immigration on the earnings of high-skill (low-skill) workers, my analysis implies that this immigrant influx reduced the wage of the average native worker by 3.2 percent. The wage impact differed dramatically across education groups, with the wage falling by 8.9 percent for high school dropouts, 4.9 percent for college graduates, 2.6 percent for high school graduates, and barely changing for workers with some college.

Although the comparison of workers across narrowly defined skill classifications reveals a sizable adverse effect of immigration on native employment opportunities, it is worth noting that we still do not fully understand why the spatial correlation approach fails to find these effects. I suspect that we can learn a great deal more about the labor market impact of immigration by documenting the many adjustments that take place, by workers and firms, both inside and outside the labor market, as immigration alters economic opportunities in many sectors of the economy. For instance, my analysis ignored the long-run capital adjustments induced by immigration, the role played by capital-skill complementarities, and the possibility 
that high-skill immigration (e.g., scientists and high-tech workers) is an important engine for endogenous technological change.

The adverse wage effects documented in this paper tell only part of the story of how the U.S. economy responded to the resurgence of large-scale immigration. The interpretation and policy implications of these findings require a more complete documentation and assessment of the many other consequences, including the potential benefits that immigrants impart on a host country. 


\section{APPENDIX 1: VARIABLE DEFINITIONS}

The data are drawn from the 1960, 1970, 1980, 1990 Public Use Microdata Samples of the U.S. Census, and the pooled 1999, 2000, 2001 Annual Demographic Supplement of the Current Population Surveys. In the 1960 and 1970 Censuses, the data extracts form a 1 percent random sample of the population. In 1980 and 1990, the immigrant extracts form a 5 percent random sample, and the native extracts form a 1 percent random sample. The analysis is restricted to men aged 18-64. A person is classified as an immigrant if he was born abroad and is either a non-citizen or a naturalized citizen; all other persons are classified as natives. Sampling weights are used in all calculations involving the 1990 Census and the CPS.

Definition of education and experience: I categorize workers into four education groups: high school dropouts, high school graduates, persons with some college, and college graduates, and use Jaeger's [1997, p. 304] algorithm for reconciling differences in the coding of the completed education variable across surveys. I assume that high school dropouts enter the labor market at age 17, high school graduates at age 19, persons with some college at age 21 , and college graduates at age 23 , and define work experience as the worker's age at the time of the survey minus the assumed age of entry into the labor market. I restrict the analysis to persons who have between 1 and 40 years of experience. Throughout much of the paper, workers are classified into one of 8 experience groups. The experience groups are defined in terms of fiveyear intervals (1-5 years of experience, 6-10, 11-15, 16-20, 21-25, 26-30, 31-35, and 36-40).

Counts of persons in education-experience groups: The counts are calculated in the sample of men who do not reside in group quarters and participate in the civilian labor force (according to the information provided by the labor force status variable for the reference week). Annual and weekly earnings: These variables are calculated in the sample of men who do not reside in group quarters, are employed in the civilian labor force, are not enrolled in school, 
report positive annual earnings, weeks worked, and weekly hours, and are not self-employed (as determined by the class of worker variable). In the 1960, 1970, and 1980 Censuses, the top coded annual salary is multiplied by 1.5 . In the 1960 and 1970 Censuses, weeks worked in the calendar year prior to the survey are reported as a categorical variable. I impute weeks worked for each worker as follows: 6.5 weeks for 13 weeks or less, 20 for 14-26 weeks, 33 for 27-39 weeks, 43.5 for 40-47 weeks, 48.5 for 48-49 weeks, and 51 for 50-52 weeks. The average log annual earnings or average log weekly earnings for a particular education-experience cell is defined as the mean of log annual earnings or log weekly earnings over all workers in the relevant population.

Fraction of time worked: This variable is calculated in the sample of men who do not reside in group quarters, are not enrolled in school, and are not in the military (as indicated by the labor force status variable for the reference week). The fraction of time worked for each person is defined as the ratio of weeks worked (including zeros) to 52. The group mean used in the analysis is the mean of this variable over the relevant population, which includes persons with zero hours worked. 
APPENDIX 2. PERCENT OF MALE LABOR FORCE THAT IS FOREIGN-BORN, BY EDUCATION AND EXPERIENCE, 1960-2000

\begin{tabular}{|c|c|c|c|c|c|c|}
\hline Education & $\begin{array}{c}\text { Years of } \\
\text { experience }\end{array}$ & 1960 & 1970 & 1980 & 1990 & 2000 \\
\hline \multirow[t]{8}{*}{ High school dropouts } & $1-5$ & 2.6 & 3.9 & 8.5 & 18.4 & 20.8 \\
\hline & $6-10$ & 3.6 & 5.4 & 13.9 & 29.7 & 44.9 \\
\hline & $11-15$ & 3.6 & 6.2 & 15.8 & 28.1 & 49.8 \\
\hline & $16-20$ & 4.3 & 6.7 & 13.5 & 28.9 & 50.0 \\
\hline & $21-25$ & 4.4 & 6.0 & 12.5 & 28.5 & 40.5 \\
\hline & $26-30$ & 5.2 & 5.5 & 11.2 & 21.4 & 40.0 \\
\hline & $31-35$ & 8.0 & 5.4 & 8.8 & 17.7 & 37.1 \\
\hline & $36-40$ & 12.3 & 5.8 & 7.9 & 15.3 & 28.4 \\
\hline \multirow[t]{8}{*}{ High school graduates } & $1-5$ & 1.2 & 2.1 & 3.2 & 8.0 & 12.3 \\
\hline & $6-10$ & 1.6 & 2.4 & 3.8 & 7.8 & 14.0 \\
\hline & $11-15$ & 2.0 & 3.1 & 4.6 & 6.9 & 14.5 \\
\hline & $16-20$ & 3.1 & 3.0 & 4.3 & 7.3 & 11.5 \\
\hline & $21-25$ & 3.0 & 3.2 & 4.8 & 7.6 & 9.4 \\
\hline & $26-30$ & 4.8 & 4.0 & 4.8 & 6.8 & 9.5 \\
\hline & $31-35$ & 7.3 & 3.4 & 4.7 & 6.5 & 10.8 \\
\hline & $36-40$ & 13.0 & 5.3 & 5.2 & 6.6 & 9.7 \\
\hline \multirow[t]{8}{*}{ Some college } & $1-5$ & 2.3 & 3.5 & 5.2 & 7.9 & 9.1 \\
\hline & $6-10$ & 3.3 & 4.2 & 5.1 & 8.3 & 10.8 \\
\hline & $11-15$ & 3.7 & 4.9 & 5.6 & 7.4 & 11.6 \\
\hline & $16-20$ & 4.6 & 4.8 & 6.1 & 6.4 & 9.3 \\
\hline & $21-25$ & 4.9 & 4.5 & 6.3 & 6.6 & 7.6 \\
\hline & $26-30$ & 5.5 & 4.7 & 5.8 & 7.0 & 5.7 \\
\hline & $31-35$ & 9.6 & 4.7 & 6.1 & 7.2 & 6.3 \\
\hline & $36-40$ & 10.7 & 6.5 & 6.3 & 6.9 & 6.0 \\
\hline \multirow[t]{8}{*}{ College graduates } & $1-5$ & 3.4 & 4.1 & 5.0 & 9.0 & 12.4 \\
\hline & $6-10$ & 4.3 & 7.2 & 6.9 & 10.8 & 15.4 \\
\hline & $11-15$ & 4.8 & 6.5 & 8.5 & 10.3 & 17.5 \\
\hline & $16-20$ & 5.0 & 5.8 & 10.5 & 9.5 & 14.6 \\
\hline & $21-25$ & 6.4 & 5.6 & 8.5 & 10.2 & 11.5 \\
\hline & $26-30$ & 7.8 & 5.7 & 7.6 & 11.6 & 10.8 \\
\hline & $31-35$ & 10.0 & 6.9 & 7.2 & 9.6 & 12.4 \\
\hline & $36-40$ & 12.5 & 9.0 & 7.2 & 9.1 & 14.5 \\
\hline
\end{tabular}

Harvard University and National Bureau of Economic Research 


\section{References}

Altonji, Joseph G., and David Card, "The Effects of Immigration on the Labor Market Outcomes of Less-Skilled Natives," in John M. Abowd and Richard B. Freeman, eds., Immigration, Trade, and the Labor Market (Chicago: University of Chicago Press, 1991).

Angrist, Joshua D., and Alan B. Krueger, "Empirical Strategies in Labor Economics," in Orley C. Ashenfelter and David Card, eds., Handbook of Labor Economics, Vol. 3A (Amsterdam: Elsevier, 1999).

Autor, David H., Lawrence F. Katz, and Alan B. Krueger, "Computing Inequality: Have Computers Changed the Labor Market?” Quarterly Journal of Economics, CXVII (1998), 1169-1213.

Becker, Gary S., Human Capital, $2^{\text {nd }}$ edition (New York: Columbia University Press, 1975).

Borjas, George J., "Assimilation, Changes in Cohort Quality, and the Earnings of Immigrants," Journal of Labor Economics, III (1985), 463-489.

Borjas, George J., "Immigrants, Minorities, and Labor Market Competition," Industrial and Labor Relations Review, XL (1987), 382-392.

Borjas, George J., "Does Immigration Grease the Wheels of the Labor Market?" Brookings Papers on Economic Activity, 1 (2001), 69-119.

Borjas, George J., Richard B. Freeman, and Lawrence F. Katz, "Searching for the Effect of Immigration on the Labor Market," American Economic Review Papers and Proceedings, LXXXVI (1996), 246-251.

Borjas, George J., Richard B. Freeman, and Lawrence F. Katz, "How Much Do Immigration and Trade Affect Labor Market Outcomes?” Brookings Papers on Economic Activity, 1 (1997), 1-67.

Bowles, Samuel, “Aggregation of Labor Inputs in the Economics of Growth and Planning: Experiments with a Two-Level CES Function," Journal of Political Economy, LXXVIII (1970), 68-81.

Card, David, "The Impact of the Mariel Boatlift on the Miami Labor Market," Industrial and Labor Relations Review, XLIII (1990), 245-257.

Card, David, "Immigrant Inflows, Native Outflows, and the Local Labor Market Impacts of Higher Immigration,” Journal of Labor Economics, XIX (2001), 22-64.

Card, David, and Thomas Lemieux, "Can Falling Supply Explain the Rising Return to College for Younger Men? A Cohort-Based Analysis," Quarterly Journal of Economics, CXVI (2001), 705-746. 
Chiswick, Barry R., "The Effect of Americanization on the Earnings of Foreign-Born Men," Journal of Political Economy, LXXXVI (1978), 897-921.

Friedberg, Rachel M., "The Impact of Mass Migration on the Israeli Labor Market," Quarterly Journal of Economics, CXVI (2001), 1373-1408.

Friedberg, Rachel M., and Jennifer Hunt, "The Impact of Immigration on Host Country Wages, Employment and Growth," Journal of Economic Perspectives, IX (1995), 23-44.

Grossman, Jean Baldwin, "The Substitutability of Natives and Immigrants in Production," Review of Economics and Statistics, LIV (1982), 596-603.

Hamermesh, Daniel, Labor Demand (Princeton, N.J.: Princeton University Press, 1993).

Jaeger, David A., "Reconciling the Old and New Census Bureau Education Questions: Recommendations for Researchers," Journal of Business and Economic Statistics, XV (1997), 300-309.

Juhn, Chinhui, Kevin M. Murphy, and Robert H. Topel, "Why Has the Natural Rate of Unemployment Increased Over Time?" Brookings Papers on Economic Activity, 2 (1991), 75-126.

Katz, Lawrence F., and Kevin M. Murphy, "Changes in the Wage Structure, 1963-87: Supply and Demand Factors," Quarterly Journal of Economics, CVII (1992), 35-78.

LaLonde, Robert J., and Robert H. Topel, "Labor Market Adjustments to Increased Immigration," in John M. Abowd and Richard B. Freeman, eds., Immigration, Trade, and the Labor Market (Chicago: University of Chicago Press, 1991).

Mincer, Jacob, Schooling, Experience, and Earnings (New York: Columbia University Press, 1974).

Murphy, Kevin M., and Finis Welch, “The Structure of Wages," Quarterly Journal of Economics, CVII (1992), 285-326.

Pischke, Jörn-Steffen, and Johannes Velling, "Employment Effects of Immigration to Germany: An Analysis Based on Local Labor Markets," Review of Economics and Statistics, LXXIX (1997), 594-604.

Samuelson, Paul A., Economics, $6^{\text {th }}$ Edition (New York: McGraw-Hill, 1964).

Schoeni, Robert F., "The Effect of Immigrants on the Employment and Wages of Native Workers: Evidence from the 1970s and 1980s," The RAND Corporation, March 1997.

Smith, James P., and Barry Edmonston, eds., The New Americans: Economic, Demographic, and Fiscal Effects of Immigration (Washington, D.C.: National Academy Press, 1997). 
Welch, Finis, "Effects of Cohort Size on Earnings: The Baby Boom Babies' Financial Bust," Journal of Political Economy, LXXXVII (1979), S65-S97.

Welch, Finis, “In Defense of Inequality,” American Economic Review, LXXXIX (1990), 1-17. 
TABLE I

Log Weekly Wage of Male Native Workers, 1960-2000

\begin{tabular}{|c|c|c|c|c|c|c|}
\hline Education & $\begin{array}{c}\text { Years of } \\
\text { experience }\end{array}$ & 1960 & 1970 & 1980 & 1990 & 2000 \\
\hline \multirow[t]{8}{*}{ High school dropouts } & $1-5$ & 5.535 & 5.758 & 5.722 & 5.494 & 5.418 \\
\hline & $6-10$ & 5.920 & 6.157 & 6.021 & 5.839 & 5.751 \\
\hline & $11-15$ & 6.111 & 6.305 & 6.166 & 6.006 & 5.932 \\
\hline & $16-20$ & 6.188 & 6.360 & 6.286 & 6.087 & 5.989 \\
\hline & $21-25$ & 6.201 & 6.413 & 6.364 & 6.180 & 6.034 \\
\hline & $26-30$ & 6.212 & 6.439 & 6.368 & 6.268 & 6.036 \\
\hline & $31-35$ & 6.187 & 6.407 & 6.419 & 6.295 & 6.086 \\
\hline & $36-40$ & 6.175 & 6.377 & 6.418 & 6.295 & 6.168 \\
\hline \multirow[t]{8}{*}{ High school graduates } & $1-5$ & 5.940 & 6.132 & 6.090 & 5.837 & 5.773 \\
\hline & $6-10$ & 6.257 & 6.476 & 6.343 & 6.159 & 6.140 \\
\hline & $11-15$ & 6.392 & 6.587 & 6.497 & 6.309 & 6.273 \\
\hline & $16-20$ & 6.459 & 6.639 & 6.609 & 6.415 & 6.323 \\
\hline & $21-25$ & 6.487 & 6.664 & 6.638 & 6.495 & 6.406 \\
\hline & $26-30$ & 6.478 & 6.677 & 6.662 & 6.576 & 6.414 \\
\hline & $31-35$ & 6.450 & 6.674 & 6.667 & 6.572 & 6.493 \\
\hline & $36-40$ & 6.435 & 6.622 & 6.657 & 6.548 & 6.460 \\
\hline \multirow[t]{8}{*}{ Some college } & $1-5$ & 6.133 & 6.322 & 6.237 & 6.085 & 6.013 \\
\hline & $6-10$ & 6.412 & 6.633 & 6.472 & 6.387 & 6.366 \\
\hline & $11-15$ & 6.535 & 6.752 & 6.641 & 6.534 & 6.489 \\
\hline & $16-20$ & 6.604 & 6.805 & 6.762 & 6.613 & 6.591 \\
\hline & $21-25$ & 6.634 & 6.832 & 6.764 & 6.711 & 6.626 \\
\hline & $26-30$ & 6.620 & 6.841 & 6.789 & 6.771 & 6.648 \\
\hline & $31-35$ & 6.615 & 6.825 & 6.781 & 6.740 & 6.662 \\
\hline & $36-40$ & 6.575 & 6.728 & 6.718 & 6.658 & 6.623 \\
\hline \multirow[t]{8}{*}{ College graduates } & $1-5$ & 6.354 & 6.612 & 6.432 & 6.459 & 6.458 \\
\hline & $6-10$ & 6.625 & 6.891 & 6.702 & 6.766 & 6.747 \\
\hline & $11-15$ & 6.760 & 7.032 & 6.923 & 6.908 & 6.943 \\
\hline & $16-20$ & 6.852 & 7.109 & 7.043 & 7.005 & 7.046 \\
\hline & $21-25$ & 6.876 & 7.158 & 7.087 & 7.112 & 7.051 \\
\hline & $26-30$ & 6.881 & 7.146 & 7.085 & 7.122 & 7.084 \\
\hline & $31-35$ & 6.867 & 7.095 & 7.079 & 7.095 & 7.074 \\
\hline & $36-40$ & 6.821 & 7.070 & 6.985 & 6.950 & 6.944 \\
\hline
\end{tabular}

The table reports the mean of the log weekly wage of workers in each education-experience group. All wages are deflated to 1999 dollars using the CPI-U series. 
TABLE II

Index of Congruence in Occupation Distributions within Education Groups, 1990

\begin{tabular}{|c|c|c|c|c|}
\hline \multirow[b]{2}{*}{$\begin{array}{l}\text { Education-experience of } \\
\text { native groups: }\end{array}$} & \multicolumn{4}{|c|}{ Experience of corresponding immigrant group } \\
\hline & $1-10$ years & $11-20$ years & 21-30 years & $31-40$ years \\
\hline \multicolumn{5}{|l|}{ High school dropouts } \\
\hline $1-10$ years & 0.709 & 0.714 & 0.671 & 0.619 \\
\hline $11-20$ years & 0.525 & 0.631 & 0.628 & 0.585 \\
\hline $21-30$ years & 0.410 & 0.527 & 0.567 & 0.566 \\
\hline $31-40$ years & 0.311 & 0.435 & 0.496 & 0.518 \\
\hline \multicolumn{5}{|l|}{ High school graduates } \\
\hline $1-10$ years & 0.682 & 0.611 & 0.498 & 0.405 \\
\hline $11-20$ years & 0.279 & 0.379 & 0.387 & 0.338 \\
\hline $21-30$ years & 0.030 & 0.184 & 0.297 & 0.272 \\
\hline $31-40$ years & -0.035 & 0.126 & 0.276 & 0.311 \\
\hline \multicolumn{5}{|l|}{ Some college } \\
\hline $1-10$ years & 0.649 & 0.571 & 0.474 & 0.291 \\
\hline $11-20$ years & 0.147 & 0.401 & 0.492 & 0.336 \\
\hline $21-30$ years & -0.052 & 0.230 & 0.432 & 0.407 \\
\hline $31-40$ years & -0.066 & 0.217 & 0.458 & 0.489 \\
\hline \multicolumn{5}{|l|}{ College graduates } \\
\hline $1-10$ years & 0.756 & 0.710 & 0.639 & 0.531 \\
\hline $11-20$ years & 0.561 & 0.673 & 0.674 & 0.593 \\
\hline $21-30$ years & 0.430 & 0.597 & 0.661 & 0.619 \\
\hline $31-40$ years & 0.422 & 0.599 & 0.688 & 0.691 \\
\hline
\end{tabular}

Equation (2) defines the index of congruence. The index is calculated separately for each pair of native and immigrant groups. 


\section{TABLE III \\ Impact of Immigrant Share on Labor Market Outcomes of Native Education-Experience Groups}

\begin{tabular}{lccc}
\hline \hline & \multicolumn{3}{c}{ Dependent variable } \\
\cline { 2 - 4 } Specification: & $\begin{array}{c}\text { Log annual } \\
\text { earnings }\end{array}$ & $\begin{array}{c}\text { Log weekly } \\
\text { earnings }\end{array}$ & $\begin{array}{c}\text { Fraction of } \\
\text { time worked }\end{array}$ \\
\hline 1. Basic estimates & -0.919 & -0.572 & -0.529 \\
2. Unweighted regression & $(0.582)$ & $(0.162)$ & $(0.132)$ \\
3. Includes women in labor force counts & -0.725 & -0.546 & -0.382 \\
& $(0.463)$ & $(0.141)$ & $(0.103)$ \\
4. Includes log native labor force as regressor & -0.919 & -0.637 & -0.511 \\
& $(0.661)$ & $(0.159)$ & $(0.148)$ \\
& -1.231 & -0.552 & -0.567 \\
& $(0.384)$ & $(0.204)$ & $(0.116)$ \\
\hline \hline
\end{tabular}

The table reports the coefficient of the immigrant share variable from regressions where the dependent variable is the mean labor market outcome for a native education-experience group at a particular point in time. Standard errors are reported in parentheses and are adjusted for clustering within education-experience cells. All regressions have 160 observations and, except for those reported in row 2 , are weighted by the sample size of the education-experience-period cell. All regression models include education, experience, and period fixed effects, as well as interactions between education and experience fixed effects, education and period fixed effects, and experience and period fixed effects. 
TABLE IV

Impact of Immigrant Share on Native Labor Market Outcomes, by Education Group

\begin{tabular}{llllcc}
\hline \hline Dependent variable: & $\begin{array}{c}\text { High school } \\
\text { dropouts }\end{array}$ & $\begin{array}{c}\text { High school } \\
\text { graduates }\end{array}$ & $\begin{array}{c}\text { Some } \\
\text { college }\end{array}$ & $\begin{array}{c}\text { College } \\
\text { graduates }\end{array}$ & $\begin{array}{c}\text { At least high } \\
\text { school graduates }\end{array}$ \\
\hline 1. Log annual earnings & -1.416 & -2.225 & -0.567 & 1.134 & -1.184 \\
& $(0.313)$ & $(0.622)$ & $(0.421)$ & $(0.436)$ & $(0.668)$ \\
2. Log weekly earnings & -0.947 & -2.074 & -1.096 & 0.610 & -0.335 \\
& $(0.164)$ & $(0.510)$ & $(0.461)$ & $(0.440)$ & $(0.612)$ \\
3. Fraction of time worked & -0.086 & 0.393 & 0.567 & 0.300 & -1.040 \\
& $(0.073)$ & $(0.251)$ & $(0.385)$ & $(0.499)$ & $(0.211)$ \\
\hline \hline
\end{tabular}

The table reports the coefficient of the immigrant share variable from regressions where the dependent variable is the mean labor market outcome for a native education-experience group at a particular point in time. Standard errors are reported in parentheses and are adjusted for clustering within experience cell (in the first four columns) and within education-experience cells (in the last column). All regression are weighted by the sample size of the education-experience-period cell. The regressions reported in the first four columns have 40 observations and include experience and period fixed effects. The regressions reported in the last column have 120 observations and include education, experience, and period fixed effects, as well as interactions between education and experience fixed effects, education and period fixed effects, and experience and period fixed effects. 
TABLE V

Impact of Immigrant Share on Labor Market Outcomes of Native State-Education-Experience Groups

\begin{tabular}{|c|c|c|c|c|}
\hline Dependent Variable: & (1) & (2) & (3) & (4) \\
\hline 1. Log annual earnings & $\begin{array}{l}-0.115 \\
(0.079)\end{array}$ & $\begin{array}{l}-0.276 \\
(0.053)\end{array}$ & $\begin{array}{l}-.253 \\
(.046)\end{array}$ & $\begin{array}{l}-.217 \\
(.068)\end{array}$ \\
\hline 2. Log weekly earnings & $\begin{array}{l}-0.124 \\
(0.042)\end{array}$ & $\begin{array}{l}-0.217 \\
(0.039)\end{array}$ & $\begin{array}{l}-.203 \\
(.038)\end{array}$ & $\begin{array}{l}-.183 \\
(.050)\end{array}$ \\
\hline 3. Fraction of time worked & $\begin{array}{l}-0.038 \\
(0.030)\end{array}$ & $\begin{array}{l}-0.100 \\
(0.015)\end{array}$ & $\begin{array}{l}-.078 \\
(.015)\end{array}$ & $\begin{array}{l}-.119 \\
(.021)\end{array}$ \\
\hline $\begin{array}{l}\text { Controls for: } \\
(\text { State } \times \text { period }),(\text { education } \times \text { period }), \\
(\text { experience } \times \text { period }),(\text { state } \times \text { education }) \\
\quad \text { fixed effects }\end{array}$ & Yes & Yes & Yes & Yes \\
\hline (State $\times$ education $\times$ experience) fixed effects & No & Yes & Yes & Yes \\
\hline (Education $\times$ experience $\times$ period) fixed effects & No & No & Yes & Yes \\
\hline $\begin{array}{l}(\text { State } \times \text { education } \times \text { period }),(\text { state } \times \\
\text { experience } \times \text { period }) \text { fixed effects }\end{array}$ & No & No & No & Yes \\
\hline
\end{tabular}

The table reports the coefficient of the immigrant share variable from regressions where the dependent variable is the mean labor market outcome for a native state-education-experience group at a particular point in time. Standard errors are reported in parentheses and are adjusted for clustering within state-education-experience cells. All regressions are weighted by the sample size of the state-education-experience-period cell and include state, education, experience, and period fixed effects. The regressions on log annual earnings or log weekly earnings have 8,153 observations; the regressions on the fraction of time worked have 8,159 observations. 
TABLE VI

Impact of Different Types of Labor Market Experience on the Log Weekly Earnings of Natives and Immigrants

\begin{tabular}{|c|c|c|c|}
\hline \multirow[b]{2}{*}{ Coefficient of: } & \multicolumn{3}{|c|}{ Group } \\
\hline & Natives & Child immigrants & Adult immigrants \\
\hline Source country experience & --- & --- & $\begin{array}{c}0.012 \\
(0.001)\end{array}$ \\
\hline Source country experience squared $\div 10$ & --- & --- & $\begin{array}{l}-0.003 \\
(0.000)\end{array}$ \\
\hline U.S. experience & $\begin{array}{c}0.056 \\
(0.000)\end{array}$ & $\begin{array}{c}0.058 \\
(0.001)\end{array}$ & $\begin{array}{c}0.032 \\
(0.002)\end{array}$ \\
\hline U.S. experience squared $\div 10$ & $\begin{array}{l}-0.010 \\
(0.001)\end{array}$ & $\begin{array}{l}-0.010 \\
(0.000)\end{array}$ & $\begin{array}{l}-0.004 \\
(0.001)\end{array}$ \\
\hline \multicolumn{4}{|l|}{ Mean value of: } \\
\hline $\begin{array}{l}\text { Source country experience } \\
\text { U.S. experience }\end{array}$ & $\begin{array}{l}--- \\
16.7\end{array}$ & 13.0 & $\begin{array}{l}10.6 \\
10.8\end{array}$ \\
\hline \multicolumn{4}{|l|}{$\begin{array}{l}\text { Marginal value of an additional year of } \\
\text { experience for immigrants: }\end{array}$} \\
\hline Source country experience & --- & --- & $\begin{array}{c}0.006 \\
(0.001)\end{array}$ \\
\hline U.S. experience & --- & $\begin{array}{c}0.033 \\
(0.001)\end{array}$ & $\begin{array}{c}0.024 \\
(0.001)\end{array}$ \\
\hline $\begin{array}{l}\text { Marginal value of an additional year of } \\
\text { experience for natives, evaluated at mean } \\
\text { value of relevant sample of immigrants }\end{array}$ & --- & $\begin{array}{c}0.031 \\
(0.000)\end{array}$ & $\begin{array}{c}0.015 \\
(0.000)\end{array}$ \\
\hline
\end{tabular}

Standard errors are reported in parentheses. The regression pools data from the 1980 and 1990 Census and has 1,141,609 observations. The dependent variable is the log of weekly earnings. The regressors include: dummy variables indicating if the worker is an adult immigrant or a child immigrant; a vector of variables indicating the worker's educational attainment, interacted with variables indicating if the worker is an adult or a child immigrant; experience (and its squared) for native workers; experience (and its square) for immigrants who arrived as children; source country experience (and its squared) for immigrants who arrived as adults; experience in the U.S. (and its squared) for immigrants who arrived as adults; dummy variables indicating the calendar year in which the immigrant arrived (1985-1989, 1980-1984, 1975-1979, 1970-1974, 1965-1969, 1960-1964, 1950-1959, and before 1950), and the interaction of this vector with a dummy variable indicating if the immigrant arrived as an adult; and a dummy variable indicating if the observation was drawn from the 1990 Census. 
TABLE VII

Impact of Immigrant Share on Labor Market Outcomes of Native Skill Groups, Using Effective Experience and Effective Skills

\begin{tabular}{lccc}
\hline \hline & \multicolumn{3}{c}{ Dependent variable } \\
\cline { 2 - 4 } Specification: & $\begin{array}{c}\text { Log annual } \\
\text { earnings }\end{array}$ & $\begin{array}{c}\text { Log weekly } \\
\text { earnings }\end{array}$ & $\begin{array}{c}\text { Fraction of time } \\
\text { worked }\end{array}$ \\
\hline 1. Effective experience & -1.025 & -0.422 & -0.611 \\
2. Using quantiles of wage distribution & $(0.506)$ & $(0.210)$ & $(0.118)$ \\
& -0.562 & -0.606 & -0.048 \\
& $(0.329)$ & $(0.158)$ & $(0.167)$ \\
\hline \hline
\end{tabular}

The table reports the coefficient of the immigrant share variable from regressions where the dependent variable is the mean labor market outcome for a native skill group (defined in terms of education-experience in row 1 or education-quantile in row 2) at a particular point in time. The quantile definition of skill groups is based on the worker's placement in each of 20 quantiles of the (within-education) native weekly wage distribution. Standard errors are reported in parentheses and are adjusted for clustering within education-experience cells (row 1) or within education-quantile cells (row 2). All regressions are weighted by the sample size of the education-experience-period cell (row 1) or the education-quantile-period cell (row 2). The regressions reported in row 1 have 128 observations; those reported in row 2 have 400 observations. The models in row 1 include education, experience, and period fixed effects, as well as interactions between education and experience fixed effects, education and period fixed effects, and experience and period fixed effects. The models in row 2 include education, quantile, and period fixed effects, as well as interactions between education and quantile fixed effects, education and period fixed effects, and quantile and period fixed effects 
TABLE VIII

Estimated Factor Price Elasticities, By Skill Group

\begin{tabular}{|c|c|c|c|c|}
\hline Education & $\begin{array}{l}\text { Years of } \\
\text { experience }\end{array}$ & $\begin{array}{l}\text { Own } \\
\text { elasticity }\end{array}$ & $\begin{array}{l}\text { Cross elasticity (within } \\
\text { education branch) }\end{array}$ & $\begin{array}{c}\text { Cross elasticity (across } \\
\text { education branches) }\end{array}$ \\
\hline \multirow[t]{8}{*}{ High school dropouts } & $1-5$ & -0.313 & -0.028 & 0.002 \\
\hline & $6-10$ & -0.330 & -0.044 & 0.003 \\
\hline & $11-15$ & -0.344 & -0.059 & 0.004 \\
\hline & $16-20$ & -0.341 & -0.056 & 0.004 \\
\hline & $21-25$ & -0.339 & -0.053 & 0.004 \\
\hline & $26-30$ & -0.352 & -0.066 & 0.004 \\
\hline & $31-35$ & -0.358 & -0.072 & 0.005 \\
\hline & $36-40$ & -0.361 & -0.076 & 0.005 \\
\hline \multirow[t]{8}{*}{ High school graduates } & $1-5$ & -0.316 & -0.030 & 0.012 \\
\hline & $6-10$ & -0.335 & -0.050 & 0.020 \\
\hline & $11-15$ & -0.343 & -0.057 & 0.023 \\
\hline & $16-20$ & -0.337 & -0.051 & 0.020 \\
\hline & $21-25$ & -0.333 & -0.047 & 0.019 \\
\hline & $26-30$ & -0.330 & -0.044 & 0.017 \\
\hline & $31-35$ & -0.323 & -0.037 & 0.015 \\
\hline & $36-40$ & -0.315 & -0.029 & 0.012 \\
\hline \multirow[t]{8}{*}{ Some college } & $1-5$ & -0.318 & -0.032 & 0.012 \\
\hline & $6-10$ & -0.339 & -0.054 & 0.020 \\
\hline & $11-15$ & -0.349 & -0.063 & 0.024 \\
\hline & $16-20$ & -0.348 & -0.063 & 0.024 \\
\hline & $21-25$ & -0.339 & -0.054 & 0.020 \\
\hline & $26-30$ & -0.324 & -0.038 & 0.015 \\
\hline & $31-35$ & -0.313 & -0.028 & 0.010 \\
\hline & $36-40$ & -0.305 & -0.019 & 0.007 \\
\hline \multirow[t]{8}{*}{ College graduates } & $1-5$ & -0.317 & -0.031 & 0.017 \\
\hline & $6-10$ & -0.335 & -0.049 & 0.026 \\
\hline & $11-15$ & -0.341 & -0.056 & 0.030 \\
\hline & $16-20$ & -0.348 & -0.062 & 0.033 \\
\hline & $21-25$ & -0.332 & -0.046 & 0.025 \\
\hline & $26-30$ & -0.318 & -0.032 & 0.017 \\
\hline & $31-35$ & -0.309 & -0.023 & 0.013 \\
\hline & $36-40$ & -0.302 & -0.016 & 0.009 \\
\hline
\end{tabular}

Equations (19)-(21) define the factor price elasticities in the three-level CES framework. For a given percent change in the numbers of workers of any specific group: The own factor price elasticity gives the percent change in that group's wage; the cross-elasticity within an education branch gives the percent change in the wage of a group with the same education but with different experience; the cross-elasticity across education branches gives the percent change in the wage of groups that have different educational attainment. 
TABLE IX

Wage Consequences of Immigrant Influx of the 1980s and 1990s (Predicted change in log weekly wage)

\begin{tabular}{cccccc}
\hline \hline & \multicolumn{5}{c}{ Education } \\
\cline { 2 - 6 } Years of experience & $\begin{array}{c}\text { High school } \\
\text { dropouts }\end{array}$ & $\begin{array}{c}\text { High school } \\
\text { graduates }\end{array}$ & $\begin{array}{c}\text { Some } \\
\text { college }\end{array}$ & $\begin{array}{c}\text { College } \\
\text { graduates }\end{array}$ & $\begin{array}{c}\text { All } \\
\text { workers }\end{array}$ \\
\hline $1-5$ & -0.065 & -0.021 & 0.004 & -0.035 & -0.024 \\
$6-10$ & -0.101 & -0.027 & 0.001 & -0.042 & -0.029 \\
$11-15$ & -0.128 & -0.036 & -0.009 & -0.059 & -0.041 \\
$16-20$ & -0.136 & -0.033 & -0.011 & -0.055 & -0.039 \\
$21-25$ & -0.108 & -0.025 & -0.008 & -0.049 & -0.033 \\
$26-30$ & -0.087 & -0.023 & 0.000 & -0.049 & -0.029 \\
$31-35$ & -0.066 & -0.022 & 0.001 & -0.050 & -0.027 \\
$36-40$ & -0.044 & -0.013 & 0.008 & -0.056 & -0.022 \\
All workers & -0.089 & -0.026 & -0.003 & -0.049 & -0.032 \\
\hline \hline
\end{tabular}

The simulation uses the factor price elasticities reported in Table VIII to predict the wage effects of the immigrant influx that arrived between 1980 and 2000. The calculations assume that the capital stock is constant. The variable measuring the group-specific immigrant supply shock is defined as the number of immigrants arriving between 1980 and 2000 divided by a baseline population equal to the average size of the native workforce (over 1980-2000) plus the number of immigrants in 1980. 


\section{A. High School Dropouts}

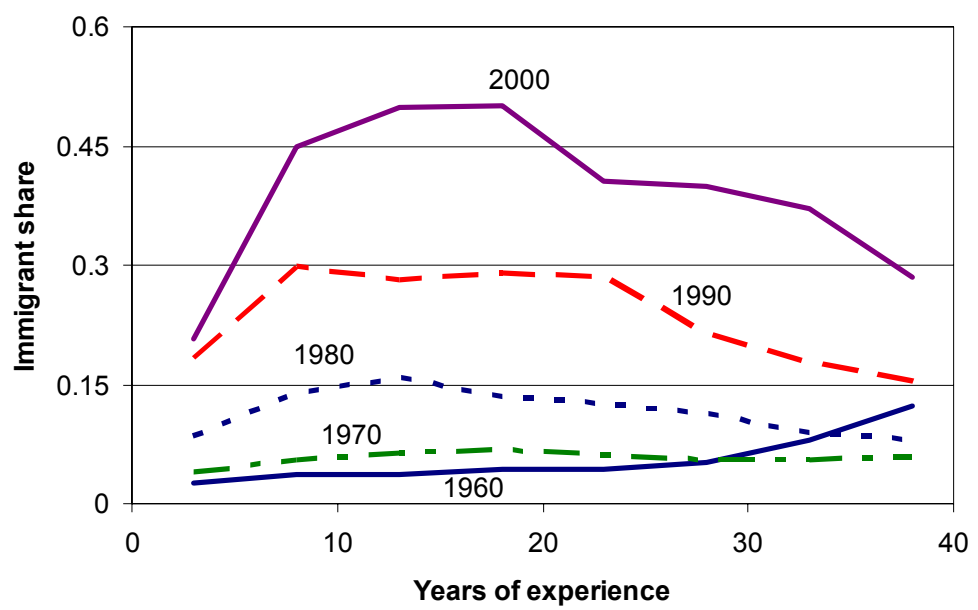

\section{Some College}

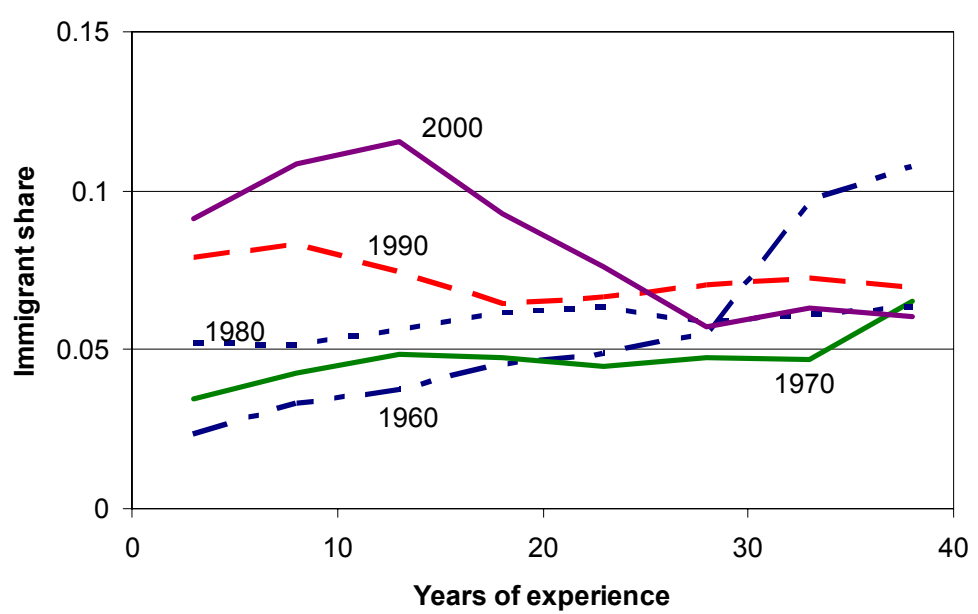

B. High School Graduates

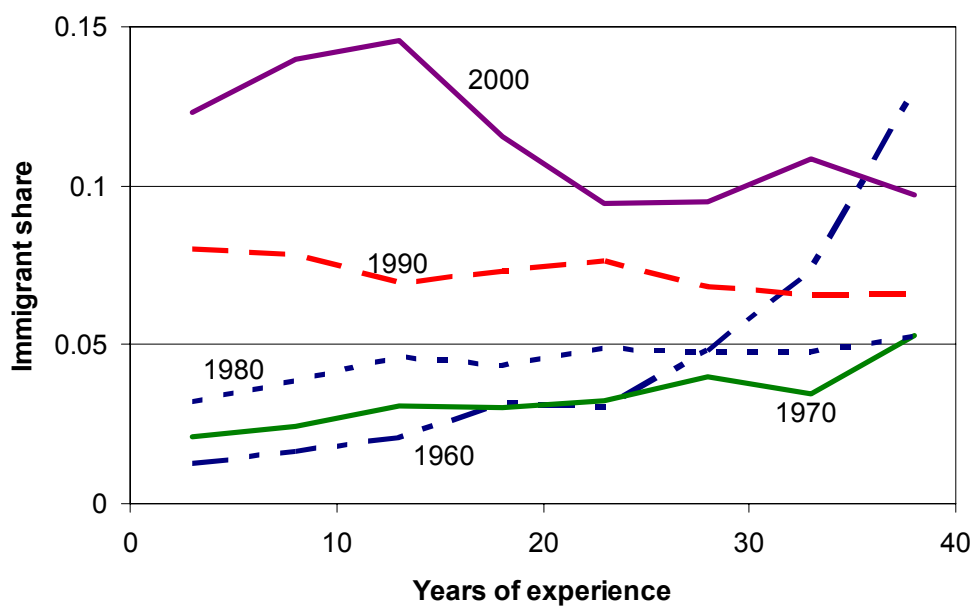

D. College Graduates

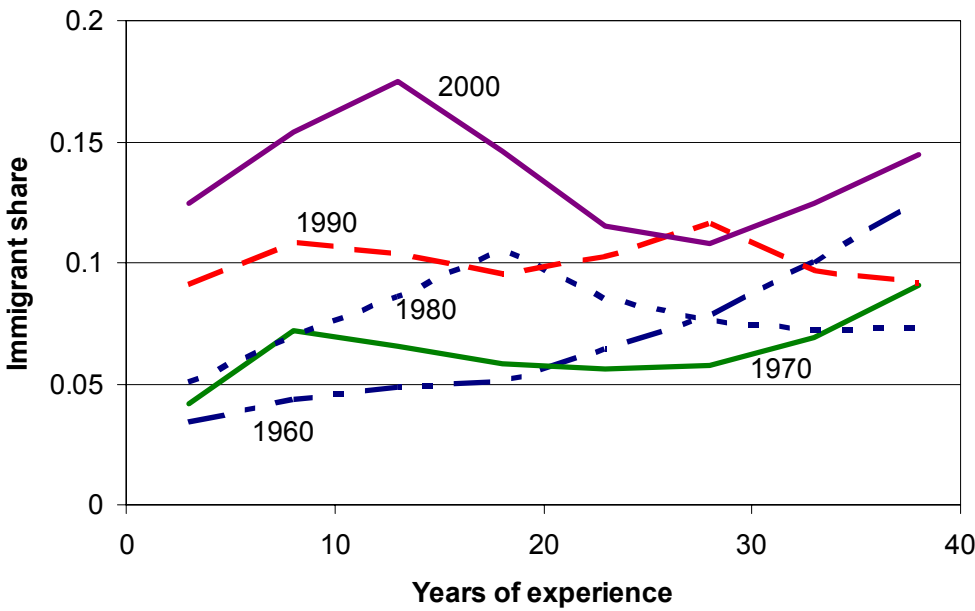

Figure I

The Immigrant Supply Shock, 1960-2000

Note: Within each education group, workers are aggregated into experience groups defined in five-year intervals. The figures use the midpoint of each experience interval to illustrate the trends. 


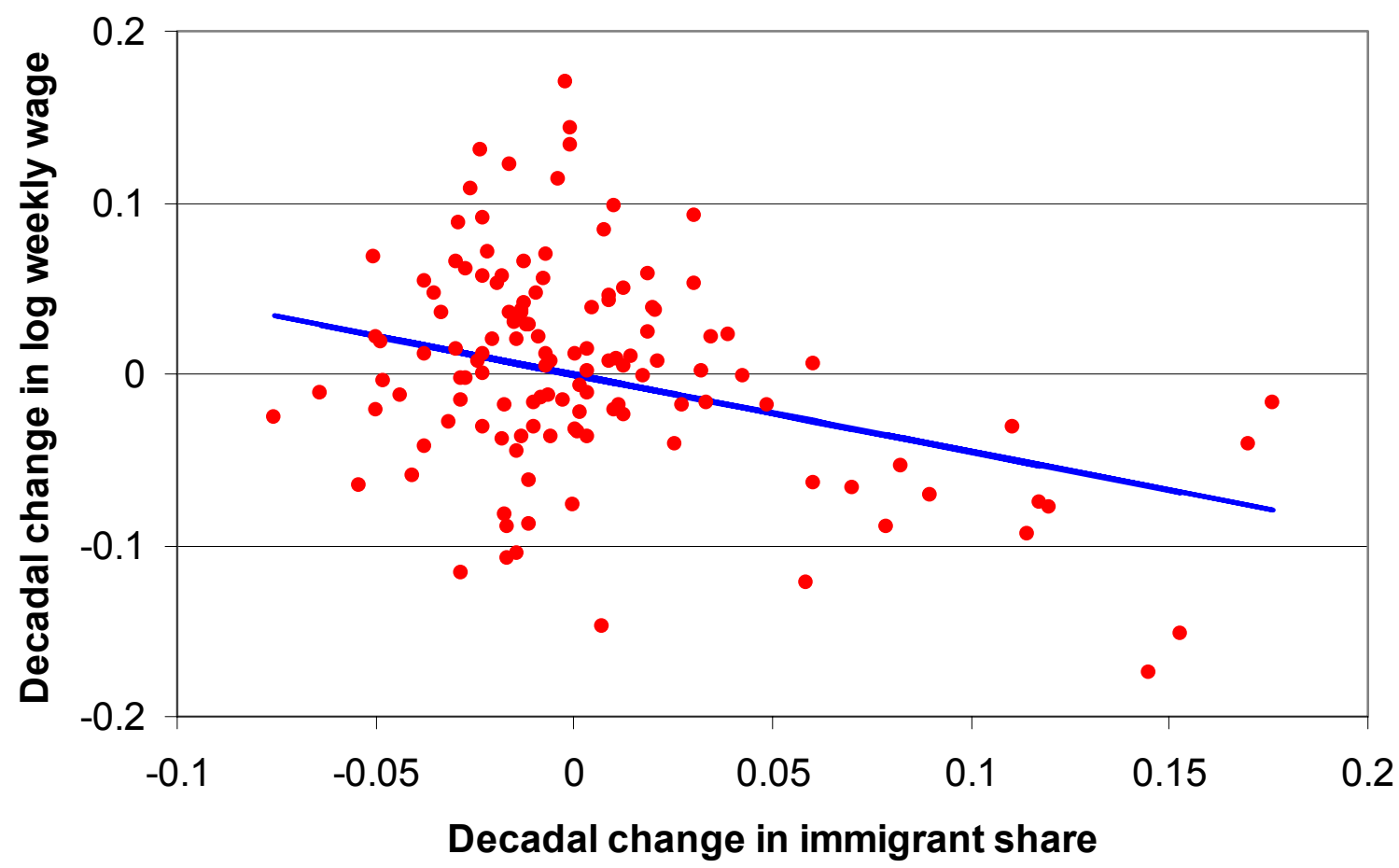

Figure II

Scatter Diagram Relating Wages and Immigration, 1960-2000

Note: Each point in the scatter represents the decadal change in the log weekly wage and the immigrant share for a native education-experience group. The data have been adjusted to remove decade effects. The regression line in the figure weighs the data by $\left(n_{0} n_{1}\right) /\left(n_{0}+n_{1}\right)$, where $n_{0}$ is the sample size of the cell at the beginning of the decade, and $n_{1}$ the sample size at the end. The coefficient of the regression line is -.450 , with a standard error of .172 . 